\title{
Culture and Learning: Confucian Heritage Learners, Social-Oriented Achievement, and Innovative Pedagogies
}

\author{
Shelen Ho
}

\section{INTRODUCTION}

An important topic of education today is "How do we prepare students for the Fourth industrial revolution (4IR)?" The 4IR is expected to generate exponential change and disruptions to industries around the world. The digital revolution is characterized by a fusion of technology and is fundamentally different from the past three revolutions in terms of velocity and scope. It is impacting every aspect of how people work and how people live, creating significant threats and opportunities. Knowledge and skills that we learned through formal education in the past are now becoming irrelevant. Employees are urged to be prepared to completely re-skill to succeed and thrive. Many believe that the answer to the challenges the world faces in this evolution is education.

Education authorities in many Asian nations have unveiled ambitious plans to revamp their education systems to embrace the 4IR. The message

S. Ho $(\bowtie)$

University of Reading, Reading, UK

(C) The Author(s) 2020

C. S. Sanger and N. W. Gleason (eds.),

Diversity and Inclusion in Global Higher Education, https://doi.org/10.1007/978-981-15-1628-3_5 
is clear that the education sector needs to adapt to change and rethink the way it delivers knowledge to remain relevant in the new industrial era. To address the challenges of the 4IR, there have been several education policy proposals. These initiatives have all encouraged teaching and learning for creativity, innovation and higher order thinking (HOT) skills ${ }^{1}$ rather than the traditional conceptual knowledge, procedural knowledge and remote memorization. Teachers are motivated to move toward studentcentered learning and constructivist learning in order to develop students as independent learners. Peer-oriented collaborative learning approaches to inculcate emotional and cultural intelligences are also desired key pedagogic strategies.

While acknowledging the pressing need to prepare the young generation with the skillsets for the 4IR, previous studies have raised appropriateness concerns about the practicality of applying these education theories across cultures. This is especially so for communities where students have been regarded as passive recipients of data. As Neuman and Bekerman argue, it would be difficult for the teacher to teach using a constructivist approach in such passive learning cultures. "Innovations which are intended to facilitate learning may be so disturbing for those affected by them - so threatening to their belief systems - that hostility is aroused and learning becomes impossible." 3

The purpose of this chapter is to highlight the gaps in education reform and use the broad lens of culture to illuminate how ethnocentrism influences the perceived possibilities and willingness to adopt educational innovations in the 4IR. The chapter begins with an overview of the 4IR and associated recent education reform efforts. The discussion then focuses on the key considerations of HOT skills and sociocultural intelligence to meet the challenges of the new industrial revolutionary age. The support for integrating HOT skills in the curriculum is provided in a case of strategic management modules. The chapter also discusses the need to consider cultural resources when applying education theories in

\footnotetext{
${ }^{1}$ Benjamin Bloom, ed., Taxonomy of Educational Objectives, Handbook I: Cognitive Domain (New York: David McKay, 1956).

${ }^{2}$ Yair Neuman and Zvi Bekerman, "Cultural Resources and the Gap Between Educational Theory and Practice," Teachers College Record 103, no. 3 (2000): 471-484.

${ }^{3}$ Hywel Coleman, ed., "Autonomy and Ideology in the English Language Classroom," in Society and the Language Classroom (Cambridge: Cambridge University Press, 1996), 11 .
} 
classrooms. In particular, the chapter discusses the application of popular pedagogic practices such as flipped instructional model and team-based learning (TBL), and how they can be used with students from Confucian Heritage Cultures (CHC). The case provided how traditional cultural values can contribute to pedagogic goal achievements and positively impact the intended learning outcomes, contrary to many previous studies on CHC learners.

\section{The Fourth Industrial Revolution and Education REFORM EFFORTS}

Klaus Schwab wrote in The Fourth Industrial Revolution, that we are standing on the brink of a technological revolution that will fundamentally alter the way we live, work, and relate to one another. The founder and Executive Chairman of the World Economic Forum described an era that will be characterized by a fusion of technologies that is blurring the lines between the physical, digital, and biological spheres. He called for governments and citizens to make sure these cutting-edge technologies are used to benefit humankind, as a complement to human creativity, empathy, and stewardship, to lift humanity into a new collective and moral consciousness based on a shared sense of destiny. ${ }^{4}$

It is increasingly clear that the rapid development of technology has changed everyone's economic, social, and cultural status quo. ${ }^{5}$ Schwab argues that this revolution is different in scale, scope, and complexity from any that have come before. ${ }^{6}$ Characterized by a range of new technologies that are fusing the physical, digital, and biological worlds, the developments are affecting all disciplines, economies, industries, and governments, and even challenging ideas about what it means to be human. The Organization for Economic Cooperation and Development's latest Employment outlook suggests that in the next fifteen to twenty years, $14 \%$ of existing jobs are at high risk of being fully automated, while

\footnotetext{
${ }^{4}$ Klaus Schwab, The Fourth Industrial Revolution (Geneva: World Economic Forum, 2016).

${ }^{5}$ Roger Chao Jr., "Educating for the Fourth Industrial Revolution," November 10, 2017, https://www.universityworldnews.com/post.php?story=20171107123728676.

${ }^{6}$ Schwab, The Fourth Industrial Revolution.
} 
another $32 \%$ are at risk of radical change. ${ }^{7}$ In another recent report on the future of jobs by the World Economic Forum, an estimated 75 million jobs may be displaced by a shift in the division of labor between humans and machines, while 133 million new roles may emerge globally by 2022.8

The blurring of technology into every part of our lives is becoming the norm. How do we educate for the 4IR? How do we prepare the next generation to be able to navigate this new world? Are our education systems and programs relevant to the 4IR? And if not, how do we reconstruct our education systems so that they are? ${ }^{9}$

In the last decade, STEM education has received tremendous attention in education reform efforts and in popular media. STEM is a curriculum based on the idea of educating students in four specific disciplines-science, technology, engineering, and mathematics - in an interdisciplinary and transdisciplinary way and often including a project or problem-based approach tied to authentic or real-world contexts. ${ }^{10}$ Much has been proclaimed about the need for more STEM programs in schools. The logic is simple: The wave of future economic prosperity lies in a workforce that is well-versed in rising job markets like science, technology, engineering, and math. Thus, there has been an increased investment in STEM initiatives in schools worldwide.

Yet there is a case to be made that our society's growing focus on STEM - while both laudable and necessary-has spawned an either/or mentality that undervalues the very subjects that might help us become the best stewards of technology. While STEM initiatives are a wonderful start into the exploration of the four areas of study, the critical process of creativity and innovation is missing. Students in STEM programs may

7 "The Future of Work Is Now. Are We Ready?," Organisation for Economic Co-operation and Development, accessed June 20, 2019, http://www.oecd.org/ employment/outlook/.

${ }^{8}$ World Economic Forum, The Future of Jobs Report 2018 (Geneva: World Economic Forum, 2018).

${ }^{9}$ Chao, "Educating for the Fourth Industrial Revolution."

${ }^{10}$ Melanie LaForce, Elizabeth Noble, Heather King, S. Holt, and Jeanne Century, The 8 Elements of Inclusive STEM High Schools (Chicago: University of Chicago, 2014); Erin E. Peters-Burton, Sharon Lynch, Tara Behrend, and Barbara Means, "Inclusive STEM High School Design: 10 Critical Components." Theory into Practice 53, no. 1 (2014): 64-71. 
have more experiential learning opportunities, but they are often limited to only science, technology, engineering, and math. Our economy requires much more than an understanding of these areas; it requires creation and ingenuity. In fact, inherent in problem- and project-based learning are opportunities for student growth in the twenty-first-century skills such as collaboration, critical thinking, creativity, accountability, persistence, and leadership. ${ }^{11}$ STEM alone does not foster these essential ingredients.

Recent years have seen intensive interest in the concept of STEAM. ${ }^{12}$ STEAM is a way to take the benefits of STEM and complete the package by integrating STEM principles in and through arts. In this sense, STEAM takes STEM to the next level ${ }^{13}$ : It allows students to connect their learning in the critical areas of science, technology, engineering, and math together with arts practices, elements, design principles, and standards to bring the whole pallet of learning to their disposal. STEAM is expected to remove limitations and replace them with wonder, critique, inquiry, and innovation. However, along with curricular innovations we need pedagogical approaches that teach students twenty-firstcentury thinking skills. What is needed is a broader and more inclusive view of STEAM that spans disciplines, with entry points across contexts, to equally engage both analytical and HOT skills in the curriculum.

As with any educational intervention, the fundamental questions to ask in this case are: Can we teach HOT skills? How do we teach HOT skills?

\section{Teaching Thinking Skills and Social Contextual INFLUENCES}

The idea that thinking can be taught is ancient. Beginning with the efforts of Plato and the introduction of Socratic dialog, we see attention to improving intelligence and promoting effective thinking as a recurring educational trend throughout the ages. Early in the twentieth century,

11 "What Is Project-Based Learning (PBL)?," Buck Institute, http://www.bie.org/ about/what_pbl; "Framework for Twenty-First Century Learning," BattelleforKids, http://www.p21.org/our-work/p21-framework.

${ }^{12}$ Anne Jolly, "STEM vs. STEAM: Do the Arts Belong?," November 18, 2014, http:// www.edweek.org/tm/articles/2014/11/18/ctq-jolly-stem-vs-steam.html.

${ }^{13}$ Susan Riley, STEAM in the Classroom Look-For List," February 1, 2018, https:// educationcloset.com/2018/02/01/steam-in-the-classroom/. 
Dewey again focused North American's attention to the importance of thinking as an educational aim. ${ }^{14}$ At the same time, Selz was advocating the idea of learnable intelligence in Europe. ${ }^{15}$ In the 1970s and 1980s, specific programs designed to teach thinking took shape, many of which continue in schools today. More recent studies also supported the importance of developing thinking skills in learning. ${ }^{16}$ Even in the early 1990s, Gauge posited "Many educators believe that specific knowledge will not be as important to tomorrow's workers and citizens as the ability to learn and make sense of new information." 17 Efforts to teach thinking have continued to proliferate in the new millennium, often becoming less programmatic in nature and more integrated within the fabric of schools.

Jarvis advocates that the role of a teacher is to facilitate learning situations so students can find things out for themselves. ${ }^{18}$ A popular quote by Peter Senge "Knowledge is constructed, not transferred" provides a vision of the modern education system. The belief is that students are not blank slates upon which knowledge is etched. They come to learning situations with already formulated knowledge, ideas, and understandings. This previous knowledge is the raw material for the new knowledge they will create. Through an active learning process, students can construct their understanding and consequently develop HOT skills. This aligns with the constructivism learning theory which has its historical roots in the work of Dewey, Bruner, Vygostsky, and Piaget. ${ }^{19}$

${ }^{14}$ John Dewey, How We Think: A Restatement of the Relation of Reflective Thinking to the Educative Process (Boston: D. C. Heath and Company, 1933).

15 O. SElz, "Attempt to Raise the Level of Intelligence," Zeitschrift fur Psychologie 134 (1935): 236-301.

${ }^{16}$ C. Norris and J. L. Poirot, Problem Solving and Critical Thinking for Computer Science Educators (Eugene: International Society for Technology in Education, 1990); Tom Morgan, "Using Technology to Enhance Learning: Changing the Chunks," Learning and Leading with Technology 23, no. 5 (1996): 49-51; Lynn A. Fortana, C. Dede, C. S. White, and W. M. Cates, Multimedia: A Gateway to Higher-Order Thinking Skills (Fairfax: George Mason University, 1993).

${ }^{17}$ As quoted in Christopher Fischer, Linda Bol, and Shana Pribesh, "An Investigation of Higher-Order Thinking Skills in Smaller Learning Community Social Studies Classrooms," American Secondary Education 39, no. 2 (2011): 5.

${ }^{18}$ Peter Jarvis, The Theory and Practice of Teaching, 2nd ed. (New York: Routledge, 2006).

${ }^{19}$ John Dewey, The Quest for Certainty (New York: Minton, 1929); Jerome S. Bruner, "The Act of Discovery," Harvard Educational Review 31, no. 1 (1961): 21-32; Lev 
A report by the World Economic Forum encourages educators to create spaces that enable people to think freely, to think divergent and creative thoughts. ${ }^{20}$ It further emphasizes that in a society where people fear having those thoughts, the likelihood of being able to enjoy progress is significantly diminished. This brings to the surface that thinking skills should be studied in a relevant social context to have an in-depth understanding of the rich picture surrounding the society's learning culture. Cross-cultural research that has examined thinking skills has found a few distinct patterns. In a study examining creativity and reasoning with college students in Hong Kong and the United States, Niu, Zhang, and Yang found that American students scored significantly higher than the Hong Kong Chinese students on a measure of creative production (writing titles for jokes). ${ }^{21}$ This difference is attributed to cultural factors that influence how individuals think and solve problems. Although no explanation for this difference was provided, Nisbett et al. argued that cultural differences represent unique systems of thought and cognition. ${ }^{22}$ Their study argues that differences in Ancient Chinese and Greek philosophies continue to exert influence today, leading East Asians to be more likely to pay attention to the "big picture," whereas Americans are more often focused on the details. This largely mirrors widely accepted sociocultural conceptions of individualism and collectivism as a social structure, ${ }^{23}$ but points to inherent differences in cognitive style and approach largely tied to the impact of culture on ways of thinking.

Vygotsky, Thought and Language (Cambridge: MIT Press, 1962); Jean Piaget, "The Psychogenesis of Knowledge and Its Epistemological Significance," in Language and Learning, edited by Massimo Piatelli-Palmarini (Cambridge: Harvard University Press, 1980), 23-34.

${ }^{20}$ World Economic Forum, "What Is the Fourth Industrial Revolution?," CN Crypto News, April 27, 2019, https://www.cncryptonews.com/what-is-the-fourth-industrialrevolution/.

${ }^{21}$ Niu Weihua, John Zhang, and Yang Yingrui, "Does Culture Always Matter: For Creativity, Yes, for Deductive Reasoning, No!," in Creativity and Reason in Cognitive Development, edited by James C. Kaufman and John Baer (New York: Cambridge University Press, 2006), 282-296.

${ }^{22}$ Richard E. Nisbett, Peng Kaiping, Incheol Choi, and Ara Norenzayan, "Culture and Systems of Thought: Holistic Versus Analytic Cognition," Psychological Review 108, no. 2 (2001): 291-310.

${ }^{23}$ S. Lau, "Collectivism's Individualism: Value Preference, Personal Control, and the Desire for Freedom Among Chinese in Mainland China, Hong Kong, and Singapore," Personality and Individual Differences 13, no. 3 (1992): 361-366. 
Thus far, the discussions have revealed two key considerations for innovations in education pedagogic strategies for the 4IR. First, the need for educators to integrate appropriate HOT skills in the curriculum. Second, the importance of social context considerations when delivering and cocreating knowledge with students. So, where do we proceed from here? At this point, the author wishes to share her own pedagogic practices in her classrooms in Malaysia where she taught strategic management modules to illustrate these two key considerations.

\section{A Case of Innovations in Pedagogic Strategies For Strategic Management Education}

In recent years, the issue of the employability skills of Malaysian university graduates has been the attention of academia, policymakers, employers, and community members. ${ }^{24}$ Literature shows that the issue of unemployment among Malaysian university graduates was associated with graduates' low employability skills. ${ }^{25}$ Various studies have associated the low employability rate of the Malaysian university graduates to the mismatch between what was taught at the universities and the skills needed for the twenty-first century. ${ }^{26}$

Intuitive thinking, critical analysis, and ability to work effectively in teams are the key attributes sought after by employers in today's competitive labor market when tasks are complex and decisions are nonprogrammable, requiring multilevel analysis and team inputs. Previous

\footnotetext{
${ }^{24}$ Ministry of Higher Education Malaysia, The National Graduate Employability Blueprint 2012-2017 (Serdang: Universiti Putra Malaysia Press, 2012).

${ }^{25}$ Idrus Hairuszila, M. H. Hazadiah, and Normah Abdullah, "Challenges in the Integration of Soft Skills in Teaching Technical Courses: Lecturer's Perspectives," Asian Journal of University Education 5, no. 2 (2009): 67-81; Morshidi Sirat, Chan Lean Heng, Munir Shuib, Shukran Abdul Rahman, Seri R. A. Kamil, and Jasvir K. N. Singh, "Employability of Graduates in Malaysia," in Employability of Graduates in Malaysia Graduate Employability in Asia, ed. UNESCO (Bangkok: UNESCO, 2012), 24-37.

${ }^{26}$ Sirat, Chan, Munir, Shukran, Seri, and Singh, "Employability of Graduates in Malaysia"; Norizan Abdul Razak, Hazita Azman, Mohd Salehuddin Abdul Aziz, Azizah Yaacob, and Wong Fook Fei, Kajian Pembentukan Ujian Kompetensi Bahasa Inggeris bagi Pelajar IPTA di Malaysia (A Study of Developing an English Language Competency Test for Malaysian IPTA Students) (Kuala Lumpur, Malaysia: Intensification of Research in Priority Areas [IRPA], 2007).
} 
studies have also found that HOT skills are one of the key competencies to be integrated into the new curriculum for the twenty-first century. ${ }^{27}$

\section{The Need for Intuitive Thinking Skills}

Spender has long advocated that the "strategic management education" industry is suffering from isomorphism and dominated by a strong industry recipe, having few differing perspectives, a step-by-step structure, and domestic orientation. ${ }^{28}$ De Wit and Meyer explained the urgent need to change the features of current strategic management teaching contents to multiple strategy perspectives, issue-based structures, and international orientation, to be relevant to the turbulent business world today. ${ }^{29}$

Not only is there a need to innovate industry-relevant curriculum content, delivering it to the students through an appropriate learning and teaching process is equally important to ensure students' achievement of intended learning objectives. Cicero (106-43 B.C.), a Roman orator and statesman once said, "Not only is there an art in knowing a thing, but also a certain art in teaching it." ${ }^{30}$ Strategic decision-making is central to organizational actions and long-term competitiveness. ${ }^{31}$ In management literature, strategic decision-making is regarded as a prevalently rational process: analytical, linear, and step-by-step. ${ }^{32}$ However, optimal strategic decision-making requires both rationality and intuition. ${ }^{33}$ David

${ }^{27}$ Sirat, Chan, Munir, Shukran, Seri, and Singh, "Employability of Graduates in Malaysia"; Norizan, Azman, Salehuddin, Azizah, and Wong, Kajian Pembentukan Ujian Kompetensi Bahasa Inggeris bagi Pelajar IPTA di Malaysia.

${ }^{28}$ J. C. Spender, Industry Recipe: An Enquiry into the Nature and Sources of Managerial Judgment (New York: Basil Blackwell, 1989).

${ }^{29}$ Bob de Wit and Ron Meyer, Strategy Synthesis: Managing Strategy Paradoxes to Create Competitive Advantage, 4th ed. (London: Cengage Learning EMEA, 2014).

${ }^{30}$ Cicero, The Treatises of M.T. Cicero, translated by C. D. Tonge (London: Bell and Dandy, 1870), 450.

${ }^{31}$ Giovanni Gavetti, Daniel Levinthal, and Willian Ocasio, "Neo-Carnegie: The Carnegie School's Past, Present, and Reconstructing for the Future," Organization Science 18, no. (2007): 523-536.

${ }^{32}$ Laure Cabantous and Jean-Pascal Gond, "Rational Decision Making as Performative Praxis: Explaining Rationality's Éternal Retour,” Organization Science 22, no. 3 (2011): 573-586.

${ }^{33}$ Said Elbanna, "Strategic Decision Making: Process Perspectives," International Journal of Management Reviews 8, no. 1 (2006): 1-20; Said Elbanna and J. Child, "Influences 
explained that although the strategic-management process is an objective, systematic approach for making major decisions in an organization, strategic management is not a pure science that lends itself to a neat, 1-2-3 approach. ${ }^{34} \mathrm{He}$ said intuition is essential and particularly useful for making decisions in situations of great uncertainty or little precedent. Intuition is commonly conceptualized as a decision-making mechanism that relies on rapid, nonconscious recognition of patterns and associations to derive affectively charged judgments. ${ }^{35}$ From years of industry experience in organization restructuring and strategic development, the author supports the literature's findings that intuition is essential to making effective strategic decisions. Albert Einstein acknowledged the importance of intuition when he said, "Imagination is more important than knowledge, because knowledge is limited, whereas imagination embraces the entire world." 36

If intuition is nonconscious thinking, how do we teach intuition? What would strategy education look like if educational orthodoxy was challenged and the teaching process was reinvented to integrate this HOT skill in curriculum delivery?

\section{Pedagogic Strategies: Team-Based Learning with Flipped Instructional Model}

As established earlier, strategic management topics are not pure science. Many strategic and marketing decisions are made in situations of great uncertainty. It requires intuition and ability to draw meaningful conclusions from critical analysis of data in a diverse team environment. Hence, in the author's design and planning of the modules, she focuses principally

on Strategic Decision Effectiveness: Development and Test of an Integrative Model," Strategic Management Journal 28 (2007): 431-453; Ann Langley, Henry Mintzberg, Patricia Pitcher, Elizabeth Posada, and Jan Saint-Macary, "Opening Up decision Making: The View from the Black Stool," Organization Science 6, no. 3 (1995): 260-279.

${ }^{34}$ Fred R. David, Strategic Management: Concepts and Cases, 15th ed. (London: Pearson, 2015).

${ }^{35}$ Erik Dane and Michael G. Pratt, "Exploring Intuition and Its Role in Managerial Decision Making," Academy of Management Journal 32, no. 1 (2007): 33-54.

${ }^{36}$ As quoted in Eugene Raudsepp, "Can You Trust Your Hunches?," Management Review 49, no. 4 (1960): 7. 
on developing HOT and effective team skills in students, so they are prepared for this reality at the workplace. A key pedagogical theory guiding the design is constructive alignment of the intended learning outcomes of developing these crucial capabilities for employability, with teaching strategies and assessment methods. ${ }^{37}$

The author finds the flipped instructional model ${ }^{38}$ and $\mathrm{TBL}^{39}$ a good fit to deliver the intended learning outcomes. Flipped learning requires a radical redefinition of the role of the teacher, the student, and the best use of time between them. It is a pedagogical approach in which direct instruction moves from the group learning space in class to the individual learning space outside class (Fig. 5.1).

The resulting group learning space is then transformed into a dynamic, interactive learning environment. In class, the teacher guides students as they apply concepts and engage creatively in the subject matter, to solve authentic, real-world problems and make collaborative decisions. ${ }^{40}$ Students construct their own understanding and knowledge of the world, through purposefully designed experiential class activities and then reflecting on those experiences. ${ }^{41}$ In constructivist teaching, the teacher plays the role of a facilitator and students as cocreators of knowledge in class.

${ }^{37}$ John Biggs and C. Tang. Teaching for Quality Learning at University, 4th ed. (Maidenhead: Open University Press, 2011).

38 Jon Bergmann and Aaron Sams, "Flipped Learning: Maximizing Face Time," $T+D$ 68, no. 2 (2014): 28-31; Kathleen Fulton, "Upside Down and Inside Out: Flip Your Classroom to Improve Student Learning," Learning and Leading with Technology 39, no. 8 (2012): 12-17; Amy Roehl, Shweta L. Reddy, and Gayla J. Shannon, "The Flipped Classroom: An Opportunity to Engage Millennial Students Through Active Learning Strategies," Journal of Family and Consumer Science 105, no. 2 (2013): 44-49.

${ }^{39}$ Dean Parmelee, Larry Michaelsen, Sandy Cook, and Patricia Hudes, "Team-Based Learning: A Practical Guide: AMEE Guide No. 65," Medical Teacher 34, no. 5 (2012): 275-287; Michael Mcinerney and L. Dee Fink, "Team-Based Learning Enhances LongTerm Retention and Critical Thinking in an Undergraduate Microbial Physiology Course," Journal of Microbiology and Biology Education 4 (2003): 3-12; Nadia Rania, Laura Migliorini, and Stefania Rebora, "Team-Based Learning and Life Skills: A Qualitative Study from Psychological Students' Point of View," Health Science Journal 10, no. 1/2 (2015): 1-7.

${ }^{40}$ Bergmann and Sams, "Flipped Learning: Maximizing Face Time."

${ }^{41}$ Carl Bereiter, "Constructivism, Socioculturalism, and Popper's World 3," Educational Researcher 23, no. 7 (1994): 21-23. 


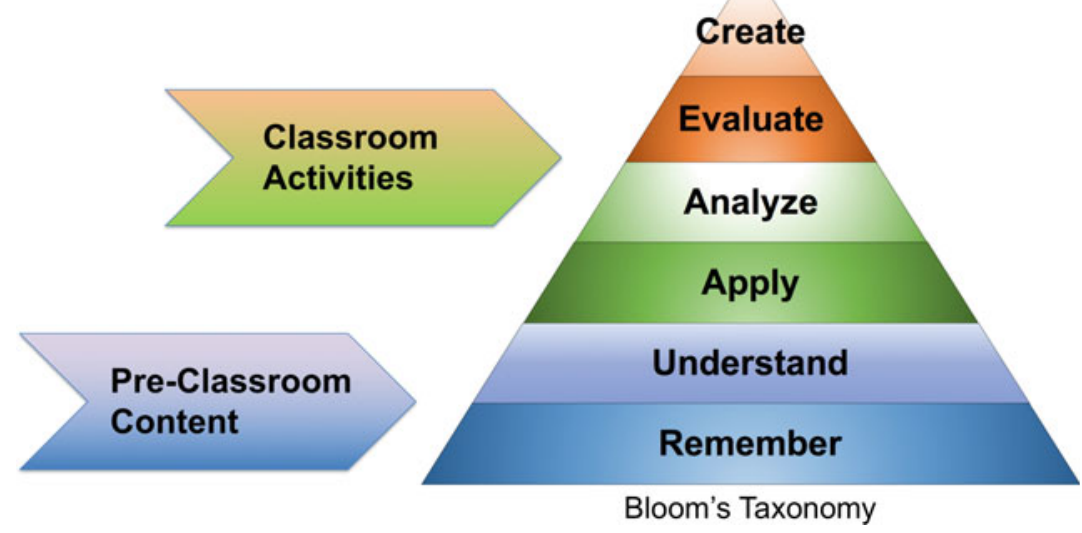

Fig. 5.1 Flipped learning

The teacher and students together, explore and address the students' preexisting conceptions and then build on them. ${ }^{42}$

To put a structure to her flipped classrooms, the author adopted the TBL instructional strategy. Team learning can offer significant benefits compared to learning individually. Many philosophies, such as Lean Six Sigma, are based around team problem solving, and some of the world's biggest corporations have adopted them. TBL is a form of collaborative learning using a special sequence of individual work, group work, and immediate feedback to create a motivational framework in which students increasingly hold each other accountable for coming to class prepared and contributing to discussion. ${ }^{43}$ The primary learning objective in TBL is to

${ }^{42}$ K. M. Oliver, "Methods for Developing Constructivism Learning on the Web," Educational Technology 40, no. 6 (2000): 5-16.

${ }^{43}$ Larry K. Michaelsen, Arletta Knight, and L. Dee Fink, Team-Based Learning: A Transformative Use of Small Groups in College Thinking (Sterling: Stylus Publishing, 2004); Larry K. Michaelsen and Michael Sweet, "The Essential Elements of Team-Based Learning," New Directions for Teaching and Learning 116, no. (2008): 7-27. 
go beyond simply covering content and focus on ensuring that students have the opportunity to practice using course concepts to solve problems while developing reasoning and HOT skills. It is designed to provide students with both conceptual and procedural knowledge. ${ }^{44}$ The methodology of TBL makes it an exemplary structure for a flipped classroom. ${ }^{45}$

Many previous studies have concluded that flipped classroom produces a wide variety of benefits for students, educational administrators, and faculty members who are engaged in the active learning process. ${ }^{46}$

${ }^{44}$ Michael Sweet and Larry Michaelsen, Team-Based Learning in the Social Sciences and Humanities: Group Work That Works to Generate Critical Thinking and Engagement (Sterling: Stylus Publishing, 2012).

45 Jennifer Moffett, “Twelve Tips for 'Flipping' the Classroom," Medical Teacher 37, no. 4 (2014): 331-336.

${ }^{46}$ Michaelsen and Sweet, "The Essential Elements of Team-Based Learning"; Shannon Flumerfelt and Greg Green, "Using Lean in the Flipped Classroom for at Risk Students," Educational Technology and Society 16, no. I (2013): 356-366; Fulton, "Upside Down and Inside Out"; Jacqueline McLaughlin, Mary Roth, Dylan Glatt, Nastaran Gharkholonarehe, Christopher Davidson, LaToya Griffin, Denise Esserman, and Russell Mumper, "The Flipped Classroom: A Course Redesign to Foster Learning and Engagement in a Health Professions School," Academic Medicine 89, no. 2 (2014): 236-243; Richard Pierce and Jeremy Fox, "Instructional Design and Assessment: Vodcasts and Active Learning Exercises in a 'Flipped Classroom' Model of a Renal Pharmacotherapy Module," American Journal of Pharmacentical Education 76, no. 10 (2012): 1-5; Cheryl Talley and Stephen Scherer, "The Enhanced Flipped Classroom: Increasing Academic Performance with Student-Recorded Lectures and Practice Testing in a 'Flipped' STEM Course," The Journal of Negro Education 82, no. 3 (2013): 339-347; Stephanie G. Wilson "The Flipped Class: A Method to Address the Challenges of an Undergraduate Statistics Course," Teaching of Psychology 40, no. 3 (2013): 193-199; Jeremy Strayer, "How Learning in an Inverted Classroom Influences Cooperation, Innovation, and Task Orientation," Learning Environments Research 15, no. 2 (2012): 171-193. 
TBL has also been widely applied across disciplines, including criminal justice, ${ }^{47}$ psychology ${ }^{48}$ sociology, ${ }^{49}$ literature and English, ${ }^{50}$ business, ${ }^{51}$ biology, ${ }^{52}$ nursing, ${ }^{53}$ and other medical fields. ${ }^{54}$ Additionally, TBL has been used not only in higher education, but also in middle and high schools. ${ }^{55}$

${ }^{47}$ Jane Tucker and Mary Brewster, "Evaluating the Effectiveness of Team-Based Learning in Undergraduate Courses," Journal of Criminal Justice Education 26, no. 4 (2015): $446-470$.

${ }^{48}$ Krisztina V. Jakobsen, Megan McIlreavy, and Sarah Marrs, “Team-Based Learning: The Importance of Attendance," Psychology Teaching and Learning 13, no. 1 (2014): 25-31.

${ }^{49}$ Erica Hunter and Bryan Robinson, "Connecting Students to the Social World: Using Team-Based Learning in the Sociology Classroom," in Team-Based Learning in the Social Sciences and Humanities, 81-97.

${ }^{50}$ Rozanne Harde and Sandy Bugeja, "Team-Based Learning in the First-Year English Classroom," in Team-Based Learning in the Social Sciences and Humanities, 143-158; Bill Robertson and Christine Reimers. "Team-Based Learning for Critical Reading and Thinking in the Literature and Great Books Courses," in Team-Based Learning in the Social Sciences and Humanities, 129-141.

${ }^{51}$ Larry K. Michaelsen, Warren E. Watson, and Robert H. Black, "A Realistic Test of Individual Versus Group Consensus Decision Making," Journal of Applied Psychology 74, no. 5 (1989): 834-839.

52 Jeffery Carmichael, “Team-Based Learning Enhances Performance in Introductory Biology," Journal of College Science Teaching 38, no. 4 (2009): 54-61.

${ }^{53}$ Michele C. Clark, Nguyen Hoang T., Chris Bray, and Ruth Levine, "Team-Based Learning in an Undergraduate Nursing Course," Journal of Nursing Education 47, no. 3 (2008): 111-117.

${ }^{54}$ Chung Eun-Kyung, Jung-Ae Rhee, Young-Hong Baik, and Oh-Sun A, "The Effect of Team-Based Learning in Medical Ethics Education," Medical Teacher 31, no. 11 (2009): 1013-1017; Daniel P. Hunt, Paul Haidet, John H. Coverdale, and Boyd Richards, "The Effect of Using Team Learning in an Evidence-Based Medicine Course for Medical Students," Teaching and Learning in Medicine 15, no. 2 (2003): 131-139; N. K. Zgheib, J. A. Simaan, and R. Sabra, "Using Team-Based Learning to Teach Pharmacology to Second Year Medical Students Improves Student Performance," Medical Teacher 32, no. 2 (2010): 130-135.

55 Scott Kubista-Hovis, “I don't Dare Teach with Inquiry-Based Teaching Methods When I Have State Testing Breathing Down My Neck," in Team-Based Learning in the Social Sciences and Humanities, 291-300; Jeanne Wanzek, Shawn Kent, Sharon Vaughn, Elizabeth Swanson, Greg Roberts, and Martha Haynes, "Implementing Team-Based Learning in Middle School Social Studies Classes," Journal of Educational Research 108, no. 4 (2014): 331-344; Shawn Kent, Jeanne Wanzek, Elizabeth Swanson, and Sharon Vaughn, "Team-Based Learning for Students with High-Incidence Disabilities in High School Social Studies Classrooms," Learning Disabilities Research and Practice 30, no. 


\section{Team-based Learning (TBL) in Flipped Classroom}

\section{Topic: Industry Analysis (2 Face-to-Face Sessions)}
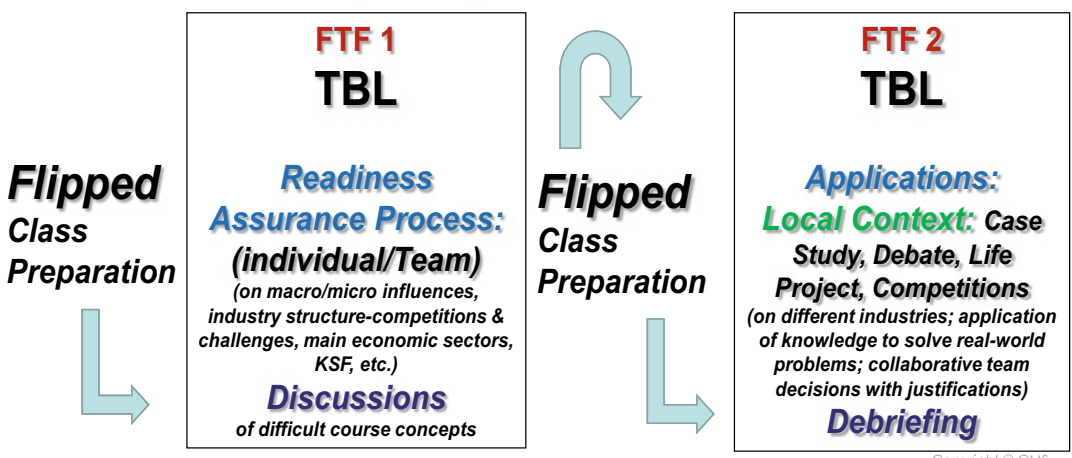

Fig. 5.2 Pedagogic strategies for strategic management in classrooms

Figure 5.2 shows an example of the author's pedagogic strategy in her flipped classrooms with the learning outcomes of students cocreating knowledge while developing HOT skills and effective teamwork behaviors. It addresses the first consideration for innovations in education pedagogic strategies for the 4IR. This is the easy part of the challenge. As the popular idiom goes, "The proof of the pudding is in the eating." The second consideration is the real test of success: understanding of the sociocultural context in the implementation of the pedagogic strategies. The practice of an innovative pedagogy requires deep deliberation of the students' sociocultural settings and learning cultures to ensure that the optimal result can be achieved from the new pedagogy. ${ }^{56}$ Does flipped classroom and TBL make sense to the students? Is there a cultural fit?

1 (2015): 3-14; Jeanne Wanzek, Sharon Vaughn, Shawn Kent, Elizabeth Swanson, Greg Roberts, Martha Haynes, Anna-Maria Fall et al., "The Effects of Team-Based Learning on Social Studies Knowledge Acquisition in High School," Journal of Research on Educational Effectiveness 7, no. 2 (2014): 183-204.

${ }^{56}$ Fariza Puteh-Behak, Darmi Ramiaida, and Mohamed Yuslina, "Implementation of a Western-Based Multiliteracies Pedagogy in Malaysia: A Socio-Cultural Perspective," Journal of Language Studies 15, no. 1 (2015): 1-24. 


\section{The Significance of Culture in Learning}

Sociocultural theory suggests that all human activities are socially, culturally, and historically constructed. ${ }^{57}$ Jaramillo asserted that Vygotsky defined society as an entity that consists of "rules and norms of the society that adults and more competent peers teach their younger initiates." 58 The cultural background of a society is a significant factor that influences human activities and shapes the society members' interpretations of the world around them, including the different conceptions about learning. This point was stressed by Hong when he defined culture as "networks of knowledge, consisting of learned routines of thinking, feeling and interacting with other people, as well as a corpus of substantive assertions and ideas about aspects of the world." 59

To understand students' learning process in a particular cultural context, it is important to consider the ways students make meaning and make sense of the world around them. Eldridge and Cranston, in their investigation of transnational education management between Australia and Thailand, asserted that the study of the sociocultural attributes of the local setting was important to determine the correct strategies for academic and operational management of a transnational higher education program. ${ }^{60}$ Novera confirmed that cultural issues were important in his investigation of the adjustment process of Indonesian students studying

${ }^{57}$ James A. Jaramillo, "Vygotsky's Sociocultural Theory and Contributions to the Development of Constructivist Curricula," Education 117, no. 1 (1996): 133-140; James P. Lantolf, ed., "Introducing Sociocultural Theory," in Sociocultural Theory and Second Language Learning (Oxford: Oxford University Press, 2000), 1-26; Mamour C. Turuk, "The Relevance and Implications of Vygotsky's Sociocultural Theory in the Second Language Classroom," ARECLS 5 (2008): 244-262.

58 Jaramillo, "Vygotsky's Sociocultural Theory and Contributions to the Development of Constructivist Curricula," 136.

${ }^{59}$ Hong Ying-yi, "A Dynamic Constructivist Approach to Culture: Moving from Describing Culture to Explaining Culture," in Understanding Culture: Theory, Research, and Application, edited by Robert S. Wyer, Chi-Yue Chiu, and Hong Ying-yi (New York: Taylor \& Francis, 2009), 4.

${ }^{60}$ Kaye Eldridge and Neil Cranston, "Managing Transnational Education: Does National Culture Really Matter," Journal of Higher Education Policy and Management 31, no. 1 (2009): 67-79. 
in Australian universities. ${ }^{61} \mathrm{He}$ interviewed 25 Indonesian postgraduate students who were studying in universities in Victoria, Australia and his study highlighted that the cultural differences between Indonesians and Australians had impacted the adjustment process of the Indonesian students.

There were also many studies that have been conducted on the area of misconceptions of Asian students' learning styles due to a lack of understanding of the local sociocultural factors that influenced learning. ${ }^{62}$ The findings confirmed that studying the sociocultural patterns of a particular society is significant in understanding the distinctive ways of learning. Ignoring students' sociocultural influences toward learning might result in inaccurate interpretation of their learning experiences. Rosenberg, Westling, and McLeskey, stated that cultural tendencies impact the way students participate in learning. ${ }^{63}$ They asserted that lack of knowledge about the culture of the students might lead to misunderstanding of the students' responses or behavior in the process of learning. They gave an example of American students' assertiveness in the classroom as this might be perceived as inappropriate by some Eastern educators. Similarly, many Asian students' quietness in the classroom might be perceived as passiveness by some Western educators.

In summary, as much as it is important for students to have a suitable pedagogical approach in achieving the goal of producing employable graduates for the 4IR, it is also important to investigate the sociocultural factors that influenced the students' learning. However, sociocultural studies is a very broad area of research and the author does not intend to deliver information that is too shallow to be useful. To provide

${ }^{61}$ Isvet A. Novera, "Indonesian Postgraduate Students Studying in Australia: An Examination of Their Academic, Social and Cultural Experiences," International Education Journal 5, no. 4 (2004): 475-487.

${ }^{62}$ Chia Mun Onn, "Major Differences Between Eastern and Western Philosophies as the Basis for Adult Education-The Singapore Experience," 2011, http://www.eaea.org/ index.php?k=12117; Gan Zhengdong, "Asian Learners’ Re-examined: An Empirical Study of Language Learning Attitudes, Strategies, and Motivation Among Mainland Chinese and Hong Kong Students," Journal of Multilingual and Multicultural Development 30, no. 1 (2009): 41-58; Shi Lijing, "The Successors to Confucianism or a New Generation? A Questionnaire Study on Chinese Students' Culture of Learning English," Language, Learning and Culture 19, no. 1 (2006): 122-147.

${ }^{63}$ Michael S. Rosenberg, David L. Westling, and James McLeskey, Special Education for Today's Teachers: An Introduction (Upper Saddle River: Prentice Hall, 2008). 
depth, the current discussion will focus on the pedagogy of flipped classroom and TBL in a Malaysian learning context with Confucian Heritage Culture (CHC).

\section{The Context: Confucian Heritage Culture (CHC)}

Asia is a geographically expansive and populous region of incredible social and cultural variation. The regions' ethnic and religious diversity is particularly striking to the outside observer. It is not uncommon for countries in the region to have dozens, if not hundreds, of local vernaculars. China has 56 recognized ethnic groups and many more undistinguished ethnic minority communities. Papua New Guinea alone contains 850 distinct language groups, $15 \%$ of the world's total. On top of this linguistic heterogeneity, all the world's major religions have found a home in the region, sometimes brought by traders, missionaries, or colonial settlers. Local rulers have variously adopted Islam, Buddhism, Hinduism, and Christianity as a state religion, although religious diversity remains the norm within the population at large. This ethnic and religious diversity continues to develop and become more complex, as long-standing cleavages are supplemented with ongoing migration within and between countries.

As with many Asian nations, Malaysia is a multiethnic, multicultural, and multilingual society, and the many ethnic groups in the country maintain separate cultural identities. ${ }^{64}$ The society of Malaysia has in fact been described as "Asia in miniature." 65 The original culture of the area stemmed from its indigenous tribes, along with the Malays who moved there in ancient times. Substantial influence exists from the Chinese and Indian cultures, dating back to when trade with those countries began in the area. Persian, Arab, and British culture have also exerted influence.

Some people are confused with the words "ethnicity" and "culture," and these words are often used interchangeably especially in the Western world. However, there are major differences between the two, evident in a multiethnic and multicultural environment as in Malaysia. Ethnicity of a

${ }^{64}$ Joel S. Kahn, Southeast Asian Identities: Culture and the Politics of Representation in Indonesia, Malaysian, Singapore and Thailand (Singapore: Institute of Southeast Asian Studies, 1998).

${ }^{65}$ Barbara W. Andaya and Leonard Y. Andaya, A History of Malaysia (London: Macmillan, 1982), xiii. 
person is related more with the racial affinities while culture is a shared set of beliefs, morals, values that are reflective of way of life. Hence, different ethnic groups could share common beliefs and values, for instance, the Confucian Heritage Culture (CHC).

$\mathrm{CHC}$ is described by education research communities as a group of Asian nation-states with their motherland and overseas population who share Confucian values, which consistently reflect in social behavior and practices, including academic outcomes and learning approaches. ${ }^{66}$ More than $85 \%$ of the student population from different ethnic groups in the author's classrooms are from the CHC background. Students completed a short questionnaire on $\mathrm{CHC}$ values at the beginning of each term. The author, from a native minority tribe, also shares $\mathrm{CHC}$ values. This presents a good scenario of an almost absolute CHC environment to explore the pedagogic practice of flipped classroom and TBL in the context.

\section{Perception: Confucian Heritage Culture (CHC)}

Asian students are often described as shy and unwilling to ask questions or speak up in class, exhibiting compliance and obedience. They are perceived to be surface learners, often relying upon rote learning, reciting the

\footnotetext{
${ }^{66}$ John Biggs, “Academic Development in Confucian Heritage Culture” (Paper, International Symposium on Child Development, Hong Kong, 1996); John Biggs, "Learning from the Confucian Heritage: So Size Doesn't Matter?," International Journal of Educational Research 29 (1998): 723-738; John Biggs, "Western Misperceptions of the Confucian-Heritage Learning Culture," in The Chinese learner: Cultural, Psychological, and Contextual Influences, edited by David Watkins and John Biggs (Hong Kong: CERC and ACER, 1996), 45-67; Sally Chan, "The Chinese Learner-A Question of Style," Education and Training 41, no. 6/7 (1999): 294-304; Lee Wing On, "The Cultural Context for Chinese Learners: Conceptions of Learning in the Confucian Tradition," in The Chinese Learner, 25-41; Roger G. Tweed and Darrin R. Lehman, "Learning Considered Within a Cultural Context: Confucian and Socratic Approaches," American Psychologist 57, no. 2 (2002): 89-99; Wang Junju, "Understanding the Chinese Learners from a Perspective of Confucianism," in Researching Cultures of Learning, edited by Martin Cortazzi and Jin Lixian (London: Palgrave Macmillan, 2013), 61-79; David A. Watkins and John Biggs, eds., Teaching the Chinese Learner: Psychological and Pedagogical Perspectives (Hong Kong: CERC and ACER, 2001); Nguyen Phuong-Mai, Cees Terlouw, and Albert Pilot, "Cooperative Learning vs Confucian Heritage Culture's Collectivism: Confrontation to Reveal Some Cultural Conflicts and Mismatch," Asia Europe Journal 3, no. 3 (2005): 403-419.
} 
thought of exemplary scholars and concerned only with absorbing knowledge rather than understanding it. This passive learning style is often attributed to Confucian core values and ethics, attached to the $\mathrm{CHC} .{ }^{67}$ Due to their Confucian inheritance, $\mathrm{CHC}$ learners also value collective harmony, refrain from expressing opinions that assert their own individuality in thought but that might clash with group norms, and habitually defer to authority rather than disagree with elders or teachers. ${ }^{68}$ Thus, "good students do not challenge their teachers; but faithfully copy and reproduce them," and in a culture where such exemplary persons' wisdom has the cachet of common sense, academic citations are even not considered necessary. 69 "Students who have been brought up in a $\mathrm{CHC}$ have learnt to value diligent study, social harmony, reverence for teachers' authority and avoidance of conflict in a face-to-face classroom environment...therefore, probing and open student-student and teacherstudent interactions are not the norm for them." 70 This is considered in contrast with the Western student learning style, which is described as assertive, independent, self-confident, and willing to ask questions and explore ways of thinking and acting. Individualism is seen as problematic

${ }^{67}$ Nola Purdie, John Hattie, and Graham Douglas, "Student Conceptions of Learning and Their Use of Self-Regulated Learning Strategies: A Cross-Cultural Comparison," Journal of Educational Psychology 88, no. 1 (1996): 87-100; M. Cortazzi and L. Jin, "Large Classes in China: Good Teachers and Interaction," in Teaching the Chinese Learner: Psychological and Pedagogical Perspectives, 115-134; Lee, "The Cultural Context for Chinese Learners"; Wang, "Understanding the Chinese Learners from a Perspective of Confucianism"; David Wu, "Parental Control: Psycho-Cultural Interpretations of Chinese Patterns of Socialization," in Growing Up the Chinese Way: Chinese Child and Adolescent Development, edited by Lau Sing (Hong Kong: The Chinese University of Hong Kong Press, 1996), 128; Michael Bond, Beyond the Chinese Face: Insight from Psychology (Hong Kong: Oxford University Press, 1992); Yang Kuo-Shu, "Sinicization of Psychological Research in Chinese Society: Directions and Issues (in Chinese)," in The Sinicization of Social and Behavioral Science Research in Chinese Societies, edited by Yang Kuo-Shu and Ch'ung-i Wen (Taipei: Institute of Ethnology, 1982), 153-187; Ganakumaran Subramaniam, "Confronting Asian Concerns in Engaging Learners to Online Education," International Education Studies 1, no. 4 (2008): 10-18.

${ }^{68}$ Jane Turner, Language in the Academy (Bristol: Multilingual Matters, 2011).

${ }^{69}$ Colin Sowden, "Plagiarism and the Culture of Multilingual Students in Higher Education Abroad," ELT Journal 59, no. 3 (2005): 227.

${ }^{70}$ Jean Chiu Yi-Ching, "Facilitating Asian Students' Critical Thinking in Online Discussions," British Journal of Educational Technology 40, no. 1 (2009): 43. 
for CHC learners. ${ }^{71}$ The other habitually ingrained values include filial piety, humaneness, ritual propriety, justice, and respect for education.

The notion that many Asian societies are Confucian, and that they share active Confucian heritages that permeate ethical, ritual, and educational life is common among education theorists. ${ }^{72}$ The Confucian concept of relational self emphasizes people's interdependency and deep commitment to social harmony and hierarchy, while excluding a serious engagement in the social ideal of equality. ${ }^{73}$ Students from many Asian countries are from birth immersed in this Confucian heritage, which has conditioned their expectations regarding academic discourse and academic standards. Asian students are criticized for not thinking deeply and not being critical enough in learning, likely leading to low-quality outcomes. ${ }^{74}$

The general perception of these theorists is that Asian students with $\mathrm{CHC}$ background would face challenges in adapting to more deductive reasoning, critical thinking, and open exchanges of ideas, which characterize many pedagogic practices common in many North American and European classrooms. The question to ask next is whether this perception is accurate. To assess whether $\mathrm{CHC}$ learners are in fact likely to struggle with more active learning pedagogies, the author has studied the implementation of flipped classrooms and TBL for the learning outcomes of HOT skills and effective teamwork behaviors among students from $\mathrm{CHC}$ background in the author's strategic management classrooms.

${ }^{71}$ Ulla Connor, Contrastive Rhetoric: Cross-Cultural Aspects of Second Language Writing (Cambridge: Cambridge University Press, 1996); Purdie, Hattie, and Douglas, "Student Conceptions of Learning and Their Use of Self-Regulated Learning Strategies."

${ }^{72}$ Insup Taylor and Martin Taylor, Writing and Literacy in Chinese, Korean and Japanese (Amsterdam: John Benjamins, 2014); Jae Park, "Metamorphosis of Confucian Heritage Culture and the Possibility of an Asian Education Research Methodology," Comparative Education 47, no. 3 (2011): 381-393; Turner, Language in the Academy; Joan Carson, "Cultural Backgrounds: What Should We Know About Multilingual Students?," TESOL Quarterly 32, no. 4 (1998): 735-740.

${ }^{73}$ Yuan Lijun, "Confucian and Feminist Notions of Relational Self and Reciprocity: A Comparative Study," Journal of East-West Thought, accessed June 25, 2019, https://www. cpp.edu/ jet/Documents/JET/Jet17/Yuanl-9.pdf.

${ }^{74}$ Shaun O'Dwyer, "Deflating the 'Confucian Heritage Culture' Thesis in Intercultural and Academic English Education," Language, Culture and Curriculum 30, no. 2 (2017): 198-211; Connor, Contrastive Rhetoric; Amanda Maxwell, Guy Curtis, and Lucia Vardanega, "Does Culture Influence Understanding and Perceived Seriousness of Plagiarism?," International Journal for Educational Integrity 4, no. 2 (2008): 25-40. 


\section{MAKing It WORK With CONFUCIAN Heritage Culture (CHC)}

The author disagrees with the general perception that $\mathrm{CHC}$ is a hindrance to the adoption of active, critical thinking-oriented pedagogic practices in $\mathrm{CHC}$ classrooms. The author posits that there has perhaps been unreflective, shallow, and superficial orientalist stereotyping of Asian students from the $\mathrm{CHC}$ traditions. While it is true that many of the traditional cultural beliefs could have influenced students' authority orientations and classroom behaviors, Confucianism is also much more than this. There is a need to have a more in-depth understanding of Confucian heritage of Asian students in the present-day state of civil society in Asian countries, in order to reduce the chances of misunderstandings and of ethnocentrism. $^{75}$

For instance, Confucian philosophy demands reflection, persistence and stoic response to pain. ${ }^{76}$ This is evident in the perseverance and resilience of many Asian businesses in difficult times. In Confucian ethics, respect for seniors and "face consciousness" to maintain harmony, provides an explanation for why students in class seldom asked questions of what teachers taught, leading to the perception of unquestioning acceptance of teachers' knowledge. ${ }^{77}$ However, not asking questions does not necessarily mean students are not paying attention or mentally active. Likewise, Cortazzi and Jin argue that students could be mentally active by

${ }^{75}$ Carson, "Cultural Backgrounds: What Should We Know About Multilingual Students?"; Gayle L. Nelson, "Comments on Ruth Spack's 'The Rhetorical Construction of Multilingual Students': Categorizing, Classifying, Labeling: A Fundamental Cognitive Process," TESOL Quarterly 32, no. 4 (1998): 727-732; O'Dwyer, "Deflating the "Confucian Heritage Culture' Thesis in Intercultural and Academic English Education."

${ }^{76}$ Clara C. Park, "Learning Style Preferences of Asian American (Chinese, Filipino, Korean, and Vietnamese) Students in Secondary Schools," Equity and Excellence in Education 30, no. 2 (1997): 68-77.

${ }^{77}$ David Murphy, “Offshore Education: A Hong Kong Perspective," Australian Universities Review 30, no. 2 (1987): 43-44; Chan, "The Chinese Learner-A Question of Style"; Chiu, "Facilitating Asian Students' Critical Thinking in Online Discussions"; Sowden, "Plagiarism and the Culture of Multilingual Students in Higher Education Abroad"; S. Chen, Learning Strategies in a Multicultural Environment (Beijing: Beijing Language and Culture University Press, 2007); Helena W. S. Hing, "Characteristics of Chinese Students' Learning Styles," International Association of Computer Science and Information Technology 62, no. 8 (2013): 36-39. 
cooperating with teachers and actively listening to teachers. ${ }^{78}$ The author shares the view of Cortazzi and Jin and disagrees that Asian students are passive learners. ${ }^{79}$ Rather, they are reflective learners demonstrated by them asking thoughtful questions after sound reflection. In fact, the Chinese word “xue wen" 學問, meaning knowledge, stresses the importance of questioning and enquiring-demonstrating a deep approach to learning.

To further illustrate the need to have a deeper understanding of the sociocultural context as the second key consideration in the adoption of innovations in education pedagogic strategies for the 4IR, the author will elaborate on two specific areas that CHC traditions have positive influences on the practice of flipped and TBL in her classrooms in delivering the expected learning outcome.

\section{CHC Inclination for Intuitive Thinking}

In the previous section, we have discussed how both intuitive and rational decision-making are valuable for strategic decision-making. We also discussed how education reforms to STEM education are designed to prepare students well in analytical thinking and making rational decisions. The initial perceived challenge is with intuitive thinking.

As mentioned earlier, people in all cultures are likely to possess both intuitive and rational reasoning systems, but cultural variation may exist in their relative accessibility to the extent that different values are placed on these reasoning systems. Many theorists have documented cultural differences in the intellectual outlooks of Asian and Western societies. ${ }^{80} \mathrm{An}$ analytic mode of thought has been held to be more prevalent in Western cultural groups. This mode is characterized by decoupling of the object

${ }^{78} \mathrm{M}$. Cortazzi and L. Jin "Cultures of Learning: Language Classrooms in China," in Society and the Language Classroom, 169-206.

${ }^{79}$ Cortazzi and Jin, "Large Classes in China: Good Teachers and Interaction."

${ }^{80}$ Fung Yu-Lan, A History of Chinese Philosophy, translated by Derek Bodde (Princeton: Princeton University Press, 1952); Geoffery Lloyd, "Science in Antiquity: The Greek and Chinese Cases and Their Relevance to the Problems of Culture and Cognition," in Modes of Thought: Explorations in Culture and Cognition, edited by David R. Olson and Nancy Torrance (Cambridge: Cambridge University Press, 1996), 15-33; Liu Shu-Hsien, "The Use of Analogy and Symbolism in Traditional Chinese Philosophy," Journal of Chinese Philosophy 1, no. 3-4 (1974): 313-338; Hajime Nakamura, The Ways of Thinking of Eastern Peoples (New York: Greenwood Press, 1988). 
from its context, assigning the object to categories based on necessary and sufficient features, and a preference for using rules, including the rules of formal logic, to explain and predict the object's behavior. In contrast, a holistic mode of thought has been held to be more prevalent in Asian cultural groups. This mode is characterized by attention to the context or field as a whole, a concern with relationships among objects and between the field and the object, and a preference for intuitive approaches, as well as dialectical reasoning, which seeks the middle-way between conflicting propositions. $^{81}$

Recent evidence indicates that some of these differences in analytic versus holistic outlooks find their counterparts in several thought processes of contemporary North Americans and East Asians. ${ }^{82}$ For instance, East Asians see social behavior as the outcome of person-context interactions, in contrast to the characteristic American view of social behavior as the unfolding of dispositions. As a result, East Asians are less prone to the fundamental attribution error, ${ }^{83}$ or the tendency to over attribute behavior to dispositions despite obvious situational constraints. ${ }^{84}$ East Asians are more field dependent than Americans, ${ }^{85}$ being more influenced by the position of the surrounding frame when judging the position of the rod in the rod-and-frame task. ${ }^{86}$ East Asians have a more holistic sense of causality: They draw on a wider range of factors to explain events.

${ }^{81}$ Ara Norenzayan, Edward. E. Smith, Beom Jun Kim, and Richard E. Nisbett, "Cultural Preferences for Formal Versus Intuitive Reasoning," Cognitive Science 26, no. (2002): 653-684.

${ }^{82}$ Nisbett, Peng, Choi, and Norenzayan, "Culture and Systems of Thought: Holistic Versus Analytic Cognition"; Norenzayan, Smith, Kim, and Nisbett, "Cultural Preferences for Formal Versus Intuitive Reasoning"; Ara Norenzayan and Ricard E. Nisbett, "Culture and Causal Cognition," Current Directions in Psychological Science 9, no. 4 (2000): 132135 .

${ }^{83}$ Lee Ross, "The Intuitive Psychologist and His Shortcomings," in Advances in Experimental Social Psychology, edited by Leonard Berkowitz (New York: Academic Press, 1977), 173-220.

${ }^{84}$ Incheol Choi, Richard E. Nisbett, and Ara Norenzayan, "Causal Attribution Across Cultures: Variation and Universality," Psychological Bulletin 125, no. 1 (1999): 47-63.

${ }^{85}$ Herman A. Witkin and John W. Berry, "Psychological Differentiation in CrossCultural Perspective," Journal of Cross-Cultural Psychology 6, no. 1 (1975): 4-87.

${ }^{86} \mathrm{Ji}$ Li-Jun, Peng Keyin, and Richard Nisbett, "Culture, Control, and Perception of Relationships in the Environment," Journal of Personality and Social Psychology 78, no. 5 (2000): 943-955. 
As a result, East Asians experience less surprise at unexpected events and show more hindsight bias, ${ }^{87}$ the tendency to view events as having been inevitable in retrospect. ${ }^{88}$ East Asians also tend to prefer dialectical resolutions to apparent contradictions, so that the contradiction is tolerated, or a compromised solution is sought. Americans are more likely to respond to contradiction by polarizing their opinions-deciding that one proposition is true and the other false. ${ }^{89}$

The East Asian cultural sphere are the countries in East Asia that were historically influenced by the Chinese culture and share a Confucian ethical philosophy. The above evidence suggests that East Asian students from the $\mathrm{CHC}$ tradition are potentially more intuitive. Confucian heritage tradition appears to have a positive impact on associative thinking capability and being naturally comfortable with gray areas. Hence, the author posits that the challenge is not about cultural support for intuitive thinking. The challenge is about how teachers can support these students with intuitive inclination by heritage, to think intuitively.

\section{The Concept of Social-Oriented Achievement Motivation (SOAM)}

Taking a social-cognitive perspective of motivation, McClelland and Maehr and Nicholls were among the pioneers who asserted that culture shapes achievement motivation. ${ }^{90}$ They maintain that every culture cultivates values or beliefs concerning qualities that are important, worth pursuing, and socially desirable. These culture-bound beliefs in turn guide the selection of achievement goals and the means of their pursuit adopted by individuals in the culture.

${ }^{87}$ Baruch Fischhoff, "Hindsight's Foresight: The Effect of Outcome Knowledge on Judgment Under Uncertainty," Journal of Experimental Psychology: Human Perception and Performance 1, no. 3 (1975): 288-299.

${ }^{88}$ Incheol Choi and Richard E. Nisbett, "The Cultural Psychology of Surprise: Holistic Theories and Recognition of Contradiction," Journal of Personality and Social Psychology 79, no. 6 (2000): 890-905.

${ }^{89}$ Peng Kaiping and Richard E. Nisbett, "Culture, Dialectics, and Reasoning About Contradiction," American Psychologist 54 (1999): 741-754.

${ }^{90}$ David McClelland, The Achieving Society (Princeton: Von Nostrand, 1961); M. L. Maehr and J. Nicholls, "Culture and Achievement Motivation: A Second Look," in Studies in Cross-Cultural Psychology, edited by Neil Warren (New York: Academic Press, 1980), 221-267. 
Originating from research in the Western tradition, ${ }^{91}$ achievement goal theory postulates that students' purposes for engaging in academic tasks serve as a motivating force that leads to achievement behaviors. The theory conceptualizes four types of goals: (1) mastery-approach goal, which emphasizes learning new knowledge and improving one's skills; (2) mastery-avoidance goal, which emphasizes the avoidance of losing skills and competence; (3) performance-approach goal, which emphasizes demonstrating one's superiority in comparison to others; and (4) performance-avoidance goal, which emphasizes the avoidance of showing one's incompetence relative to others. According to Spence, these motivational constructs mirror Western individualist values well. ${ }^{92}$ Observing that people in the Eastern collectivist societies are driven by achievement motivations inherently different from those theorized in the West, Yu and Yang propose the concepts of individual-oriented and social-oriented achievement motivations (SOAM). ${ }^{93}$ Individual-oriented achievement motivation (IOAM) describes the tendency to pursue internally determined goals in one's own way, whereas SOAM refers to the tendency to achieve externally determined goals in a socially desirable way. Since there are value differences underlying the two, Yu and Yang believe that IOAM is more salient among people in individualist societies, whereas SOAM predominates among those in the collectivist tradition. Other researchers have made similar observations in achievement motivation with Eastern collectivistic societies and Western individualistic societies. ${ }^{94}$ While contending that there are underlying differences between the concepts of

${ }^{91}$ Andrew J. Elliot, "A Conceptual History of the Achievement Goal Construct," in Handbook of Competence and Motivation, edited by Andrew J. Elliot and Carol S. Dweck (New York: The Guilford Press, 2005), 52-72.

92 Janet T. Spence, “Achievement American Style: The Rewards and Costs of Individualism," American Psychologist 40, no. 12 (1985): 1285-1295.

${ }^{93} \mathrm{Yu}$ An-Bang and Yang Kuo-Shu, "The Nature of Achievement Motivation in Collectivist Societies," in Individualism and Collectivism: Theory, Method, and Applications, edited by Uichol Kim, Harry C. Triandis, Cigdem Kagitcibasi, Sang-Chin Choi, and Gene Yoon (Thousand Oaks: Sage, 1994), 239-250.

${ }^{94}$ Yang Kuo-Shu and Yu An-Bang, "Social-Oriented and Individual-Oriented Achievement Motives: Conceptualization and Measurement" (Paper, Symposium on Chinese Personality and Social Psychology for the XXIVth International Congress of Psychology, Sydney, 1988); Yu An-Bang and Yang Kuo-Shu, "Social-Oriented and Individual-Oriented Achievement Motivation: A Conceptual and Empirical Analysis (in Chinese)," Bulletin of the Institute of Ethnology, Academia Sinica 64 (1987): 51-98; Yu and Yang, "The Nature of Achievement Motivation in Collectivist Societies"; Yu An-Bang, "Ultimate 
individual-oriented and SOAM, the author argues that the two can coexist and function interactively in motivating students' achievement behaviors, with CHC.

Confucianism is the cornerstone of traditional Chinese culture. Confucian traditions emphasize group orientation, interpersonal harmony, acceptance of authority, and the importance of education and academic attainments. Chang, Wong, and Teo posit that the critical question concerning achievement motivation in the collective context seem to be whether in cultures where the collective is emphasized, the individuals have the same kind of intrinsic motives to achieve? ${ }^{95}$ To accept the possibility that individuals in the collective context might be low on the motivation to achieve, one might have to accept the assumptions that (1) the motivation to achieve and the motivation to affiliate are necessarily at odds with each other and (2) that individual achievement and the collective goals are at each other's expenses. In their studies, Chang, Wong, and Teo contend that these assumptions are not always true in the Chinese cultural context. They argue that in the Chinese context, individual achievement in terms of mastery in academic settings serves both the taskoriented motivations as well as the social-oriented motivations. In the academic settings, individual Chinese might approach achievement via both the individually oriented and the socially oriented goal conceptualizations and behavioral scripts.

In recent years, economic reforms have accelerated the process of modernization, openness, and globalization in the region. In responding to these rapid changes, educational systems in many Asian societies began to emphasize values oriented to individuality, independent thinking, and creativity. ${ }^{96}$ There is a trend that individualist-oriented values are now more increasingly adopted by Asians, especially the youth. In the $\mathrm{CHC}$

Life Concerns, Self, and Chinese Achievement Motivation," in The Handbook of Chinese Psychology, edited by Michael H. Bond (Hong Kong: Oxford University Press, 1996), 227-246. Farideh Salili, "Accepting Personal Responsibility for Learning," in The Chinese Learner, 86-105; Vivienne Tao and Hong Ying-Yi, "When Academic Achievement Is an Obligation-Perspectives from Social-Oriented Achievement Motivation," Journal of Cross-Cultural Psychology 45, no. 1 (2014): 110-136.

95 Chang Weining C., Wong Wing-Keung, and Grace Teo, "The Socially Oriented and Individually Oriented Achievement Motivation of Singaporean Chinese Students," Journal of Psychology in Chinese Societies 1, no. 2 (2000): 39-63.

${ }^{96}$ John Hawkins, N. Zhou, and J. Lee, "China: Balancing the Collective and the Individual," in Value Education for Dynamic Societies: Individualism or Collectivism, edited 
traditions, social recognition and task-mastery are intertwined. ${ }^{97}$ Confucian ethics place high value on both individual competence as well as social harmony. ${ }^{98}$ In many Western cultures, an individual's success is often defined as performance excellence in achievement goals chosen based on the individual's own aspiration. Contrary to this individually oriented notion, achievement to the $\mathrm{CHC}$ learners serves a dual function: realization of the individual's aspiration and gaining societal approval. ${ }^{99}$ Children's achievement is regarded as the most important objective in parents' expectations. ${ }^{100}$ To meet this dual demand, the CHC learners often choose to excel in achievement goals, normatively defined by the society. In other words, for an individual, achievement is defined as individual reaching success within the collective context. ${ }^{101}$ An individual's achievement is not achievement in isolation but achievement in collective. Academic achievement is hence a social endeavor to bring pride to the family and glorify the ancestry (光宗耀祖).

On the other hand, Confucius maintained that in an ideal society, power prestige and fortune can be attained through individual mastery of skills and knowledge. The age-old civil servants' examination in China further institutionalized this belief and the actual practice of the path to success. Task-related motives can thus be seen as intimately related to satisfaction of socially related needs. These positive correlations suggest that

by William K. Cummings, Maria T. Tatto, and John Hawkins (Hong Kong: Comparative Educational Research Center, 2001), 191-206.

${ }^{97}$ Rebecca P. Ang and Chang Weining C., "Impact of Domain-Specific Locus of Control on Need for Achievement and Affiliation," The Journal of Social Psychology 139, no. 4 (1999): 527-530; Wm Theodore de Bary, Learning for One's Self: Essays on the Individual in Neo-Confucian Thought (New York: Columbia University Press, 1991).

${ }^{98}$ Chang Weining C. and Wong Wing-Keung, "Rational Traditionalism: Chinese Values in Singapore," in Values and Development: A Multi-Disciplinary Approach with Some Comparative Studies, edited by Hank Lim and Ranjit Singh (Singapore: Center for Advanced Studies, 1998), 295-308.

${ }^{99}$ Yang and Yu, "Social-Oriented and Individual-Oriented Achievement Motives."

${ }^{100}$ Yang Kuo-Shu, "Chinese Personality and Its Change," in The Psychology of the Chinese People, edited by Michael H. Bond (Hong Kong: Oxford University Press, 1986), 106-170.

${ }^{101}$ Tu Weiming, Confucian Thought: Selfhood as Creative Transformation (Albany: State University of New York Press, 1985); Yang and Yu, "Social-Oriented and IndividualOriented Achievement Motives"; Yu An-Bang, "Socializational Factors of Individual's Achievement Motivation in Family," Bulletin of the Institute of Ethnology 71 (1991): 87-132. 
within the $\mathrm{CHC}$ community, an individual's striving toward achievement is not seen as incompatible with that individual's striving toward social approval. With this dual emphasis on both the individual as well as the collective, a happy medium for the CHC students would be provided by achievement goals that could integrate both individual-oriented achievement as well as social-oriented communion needs. ${ }^{102}$ Spence postulated that different societies find different collective solutions to manage these two senses of motivation to achieve and the motivation for affiliation. ${ }^{103}$

The author contends that teachers play an important role in inspiring and supporting individual student's motivation to achieve success, in both the socially oriented and individual-oriented achievement goals. With CHC students where the communion sense of self prevails, there is a need for teachers innovating pedagogic strategies to understand the culture-achievement relations and how the motivation to achieve regulates the selection of goals and goal-directed behaviors of individual students. For instance, the author posits that TBL is culturally appropriate for CHC learners. In a collective-oriented culture, students find comfort and security by engaging in discussions in small groups rather than asking questions or voicing one's opinion openly in a larger class. ${ }^{104}$ The teacher can have more engaging conversations with small groups applying scaffolding strategies to cocreate knowledge. In addition, teacher-student relationships are highly valued and viewed on long-term bases. ${ }^{105}$ Biggs believed that Asian students were more active in one-to-one interactions with teachers and engaging in peer discussion outside instead of within class itself. ${ }^{106}$ Group-society norms of relationships extend beyond classroom.

102 Chang, Wong, and Teo, "The Socially Oriented and Individually Oriented Achievement Motivation of Singaporean Chinese Students."

103 Spence, "Achievement American Style: The Rewards and Costs of Individualism."

${ }^{104}$ Cortazzi and Jin, "Cultures of Learning: Language Classrooms in China"; William Littlewood, "Students' Attitudes to Classroom English Learning: A Cross-Cultural Study," Language Teaching Research 5, no. 1 (2001): 3-28.

105 Cheng Xiaotang, “Asian Students' Reticence Revisited," System 28, no. 3 (2000): 435-446; Wang, "Understanding the Chinese Learners from a Perspective of Confucianism."

106 Biggs, "Academic Development in Confucian Heritage culture." 
The author believes this trust and respect for teachers are two important components for teachers to create a supportive and nurturing learning environment for students, especially with new innovative pedagogic practices, to develop HOT skills. Asking students to embrace new and possibly uncomfortable modes of learning, such as flipped classroom and TBL, will work best when students trust in their teacher's expertise and knowledge. Among CHC learners, there is a cultural expectation that teachers are knowledgeable and trustworthy intellectual guides. This trust can be harnessed to compassionately encourage students to embrace more active learning approaches and develop critical thinking skills.

\section{ConcLusion}

This chapter has highlighted the gaps in education reform for the 4IR to include HOT skills and sociocultural understanding. It is hard to imagine any educator who is not aware of the importance of teaching HOT skills to prepare the young generation to live in the twenty-first century. The premise that research literature supports the teaching and learning of HOT skills is no longer an issue for contention. ${ }^{107}$ HOT skills should be an integral part of teaching and learning especially at the higher education level. Thinking skills should be part of the curriculum if students are to solve problems individually, cooperatively, and creatively.

The challenge lies with how best to teach these HOT skills. This chapter discusses strategies to fuse and integrate innovative pedagogic practice of flipped instructional model and TBL that would foster HOT skills among students from $\mathrm{CHC}$ contexts. The author also argues that the collaborative learning embedded in TBL is culturally appropriate for the collectivist community.

Seo and Koro-Ljungberg believe that without understanding the role of cultural identity and heritage embedded in a particular cultural framework, higher education cannot achieve one of its most important goals: to provide quality education for all. ${ }^{108}$ While the author agrees with the

${ }^{107}$ Yee Mei Hong, Widad Binti Othman, Jailani Bin Md Yunos, Tee Tze Kiong, Razali Bin Hassan, and Mimi Mohaffzya Binti Mohamad, "The Level of Marzano Higher Order Thinking Skills Among Technical Education Students," International Journal of Social Science and Humanity 1, no. 2 (2011): 121-125.

${ }^{108}$ Seo Seonjin and Mirka Koro-Ljungberg, "A Hermeneutical Study of Older Korean Students' Experiences in American Higher Education: From Confucianism to Western 
importance of culturally responsive teaching for today's educators, the author argues that the understanding of traditional values should not be superficial; it should be critically evaluative. Students who come from a $\mathrm{CHC}$ have been described negatively in the literature for their supposedly passive learning style. The author challenges this criticism and advocates that there has been insufficient depth of understanding of the cultural values beneath the surface of social life to uncover the assumptions of this community. Most times, a narrow aspect of a culture is captured and shared, compounding misunderstandings.

The author discusses Confucian heritage cultural inclination toward intuition and how CHC students' achievement motivations could be strategically harnessed to support innovative pedagogic practices. The author argues that Confucian heritage has limited explanatory value in characterizing the observed learning habits of Asian students. It is out of touch with the realities of today's diverse Asian societies. There is Confucian heritage, but its historical diversity and philosophical sophistication have often been poorly comprehended and its contemporary influence in education has been exaggerated. There are other, more plausible explanations for the observed Asian learning habits, which teachers and researchers should also explore. More attention should be given to situation-specific factors of teaching methodologies, learning environment, learning habits rather than cultural factors. Perhaps, we need different attitudes about the world, to view cultures as unique and special, and to consider how cultural differences can be leveraged to enhance student learning.

\section{BIBLIOGRAPHY}

Andaya, Barbara W., and Leonard Y. Andaya. A History of Malaysia. London: Macmillan, 1982.

Ang, Rebecca P., and Chang Weining C. "Impact of Domain-Specific Locus of Control on Need for Achievement and Affiliation." The Journal of Social Psychology 139, no. 4 (1999): 527-530.

BattelleforKids. "Framework for Twenty-First Century Learning." http://www. p21.org/our-work/p21-framework.

Educational Values," Journal of Studies in International Education 9, no. 2 (2005): 164187. 
Bereiter, Carl. “Constructivism, Socioculturalism, and Popper's World 3." Educational Researcher 23, no. 7 (1994): 21-23.

Bergmann, Jon, and Aaron Sams. "Flipped Learning: Maximizing Face Time." $T+D$ 68, no. 2 (2014): 28-31.

Biggs, John. “Academic Development in Confucian Heritage Culture." Paper presented at the International Symposium on Child Development, Hong Kong, 1996.

—. "Learning from the Confucian Heritage: So Size Doesn't Matter?" International Journal of Educational Research 29 (1998): 723-738.

- "Western Misperceptions of the Confucian-Heritage Learning Culture." In The Chinese Learner: Cultural, Psychological, and Contextual Influences, edited by David Watkins and John Biggs, 45-67. Hong Kong: CERC and ACER, 1996.

Biggs, John, and C. Tang. Teaching for Quality Learning at University. 4th ed. Maidenhead: Open University Press, 2011.

Bloom, Benjamin S., ed. Taxonomy of Educational Objectives, Handbook I: Cognitive Domain. New York: David McKay, 1956.

Bond, Michael. Beyond the Chinese Face: Insight from Psychology. Hong Kong: Oxford University Press, 1992.

Bruner, Jerome S. “The Act of Discovery." Harvard Educational Review 31, no. 1 (1961): 21-32.

Buck Institute. "What Is Project-Based Learning (PBL)?” http://www.bie.org/ about/what_pbl.

Cabantous, Laure, and Jean-Pascal Gond. "Rational Decision Making as Performative Praxis: Explaining Rationality's Éternal Retour." Organization Science 22 , no. 3 (2011): 573-586.

Carmichael, Jeffery. "Team-Based Learning Enhances Performance in Introductory Biology." Journal of College Science Teaching 38, no. 4 (2009): 54-61.

Carson, Joan. "Cultural Backgrounds: What Should We Know About Multilingual Students?” TESOL Quarterly 32, no. 4 (1998): 735-740.

Chan, Sally. "The Chinese Learner-A Question of Style." Education and Training 41, no. 6/7 (1999): 294-304.

Chang, Weining C., and Wong Wing-Keung. "Rational Traditionalism: Chinese Values in Singapore." In Values and Development: A Multi Disciplinary Approach with Some Comparative Studies, edited by Hank Lim and Ranjit Singh, 295-308. Singapore: Center for Advanced Studies, 1998.

Chang, Weining C., Wong Wing-Keung, and Grace Teo. "The Socially Oriented and Individually Oriented Achievement Motivation of Singaporean Chinese Students." Journal of Psychology in Chinese Societies 1, no. 2 (2000): 39-63.

Chao, Roger, Jr. "Educating for the Fourth Industrial Revolution." November 10, 2017. https://www.universityworldnews.com/post.php?story= 20171107123728676. 
Chen, S. Learning Strategies in a Multicultural Environment. Beijing: Beijing Language and Culture University Press, 2007.

Cheng, Xiaotang. "Asian Students' Reticence Revisited." System 28, no. 3 (2000): 435-446.

Chia, Mun Onn. "Major Differences Between Eastern and Western Philosophies as the Basis for Adult Education-The Singapore Experience." 2011. http:// www.eaea.org/index.php?k=12117.

Chiu, Jean Yi-Ching, "Facilitating Asian Students' Critical Thinking in Online Discussions." British Journal of Educational Technology 40, no. 1 (2009): 4257.

Choi, Incheol, and Richard E. Nisbett. "The Cultural Psychology of Surprise: Holistic Theories and Recognition of Contradiction." Journal of Personality and Social Psychology 79, no. 6 (2000): 890-905.

Choi, Incheol, Richard E. Nisbett, and Ara Norenzayan. "Causal Attribution Across Cultures: Variation and Universality." Psychological Bulletin 125, no. 1 (1999): 47-63.

Chung, Eun-Kyung, Jung-Ae Rhee, Young-Hong Baik, and Oh-Sun A. "The Effect of Team-Based Learning in Medical Ethics Education." Medical Teacher 31, no. 11 (2009): 1013-1017.

Cicero. The Treatises of M.T. Cicero. Translated by C. D. Tonge. London: Bell and Dandy, 1870.

Clark, Michele C., Nguyen Hoang T., Chris Bray, and Ruth Levine. "TeamBased Learning in an Undergraduate Nursing Course." Journal of Nursing Education 47, no. 3 (2008): 111-117.

Coleman, Hywel, ed. "Autonomy and Ideology in the English Language Classroom." In Society and the Language Classroom, 1-16. Cambridge: Cambridge University Press, 1996.

Connor, Ulla. Contrastive Rhetoric: Cross-Cultural Aspects of Second Language Writing. Cambridge: Cambridge University Press, 1996.

Cortazzi, M., and L. Jin "Cultures of Learning: Language Classrooms in China." In Society and the Language Classroom, edited by Hywel Coleman, 169-206. Cambridge: Cambridge University Press, 2016.

- "Large Classes in China: Good Teachers and Interaction." In Teaching the Chinese Learner: Psychological and Pedagogical Perspectives, edited by David A. Watkins and John Biggs, 115-134. Hong Kong: CERC and ACER, 2001. Dane, Erik, and Michael G. Pratt. "Exploring Intuition and Its Role in Managerial Decision Making." Academy of Management Journal 32, no. 1 (2007): 33-54.

David, Fred R. Strategic Management: Concepts and Cases. 15th ed. London: Pearson, 2015.

de Bary, Wm. Theodore. Learning for One's Self: Essays on the Individual in Neo-Confucian Thought. New York: Columbia University Press, 1991. 
de Wit, Bob, and Ron Meyer. Strategy Synthesis: Managing Strategy Paradoxes to Create Competitive Advantage. 4th ed. London: Cengage Learning EMEA, 2014.

Dewey, John. How We Think: A Restatement of the Relation of Reflective Thinking to the Educative Process. Boston: D. C. Heath and Company, 1933.

- The Quest for Certainty. New York: Minton, 1929.

Elbanna, Said. "Strategic Decision Making: Process Perspectives." International Journal of Management Reviews 8, no. 1 (2006): 1-20.

Elbanna, Said, and J. Child. "Influences on Strategic Decision Effectiveness: Development and Test of an Integrative Model." Strategic Management Journal 28 (2007): 431-453.

Eldridge, Kaye, and Neil Cranston. "Managing Transnational Education: Does National Culture Really Matter." Journal of Higher Education Policy and Management 31, no. l (2009): 67-79.

Elliot, Andrew J. "A Conceptual History of the Achievement Goal Construct." In Handbook of Competence and Motivation, edited by Andrew J. Elliot and Carol S. Dweck, 52-72. New York: The Guilford Press, 2005.

Fariza, Puteh-Behak, Darmi Ramiaida, and Mohamed Yuslina. "Implementation of a Western-Based Multiliteracies Pedagogy in Malaysia: A Socio-Cultural Perspective." Journal of Language Studies 15, no. 1 (2015): 1-24.

Fischer, Christopher, Linda Bol, and Shana Pribesh. "An Investigation of HigherOrder Thinking Skills in Smaller Learning Community Social Studies Classrooms." American Secondary Education 39, no. 2 (2011): 5-26.

Fischhoff, Baruch. "Hindsight's Foresight: The Effect of Outcome Knowledge on Judgment Under Uncertainty." Journal of Experimental Psychology: Human Perception and Performance 1, no. 3 (1975): 288-299.

Flumerfelt, Shannon, and Greg Green. "Using Lean in the Flipped Classroom for at Risk Students." Educational Technology and Society 16, no. 1 (2013): 356-366.

Fortana, Lynn A., C. Dede, C. S. White, and W. M. Cates. Multimedia: A Gateway to Higher-Order Thinking Skills. Fairfax: George Mason University, 1993.

Fulton, Kathleen. "Upside Down and Inside Out: Flip Your Classroom to Improve Student Learning." Learning and Leading with Technology 39, no. 8 (2012): 12-17.

Fung, Yu-Lan. A History of Chinese Philosophy. Translated by Derek Bodde. Princeton: Princeton University Press, 1952.

Gan, Zhengdong. "Asian Learners' Re-examined: An Empirical Study of Language Learning Attitudes, Strategies, and Motivation Among Mainland Chinese and Hong Kong Students." Journal of Multilingual and Multicultural Development 30, no. 1 (2009): 41-58. 
Gavetti, Giovanni, Daniel Levinthal, and Willian Ocasio. "Neo-Carnegie: The Carnegie School's Past, Present, and Reconstructing for the Future." Organization Science 18, no. (2007): 523-536.

Hairuszila, Idrus, M. H. Hazadiah, and Normah Abdullah. "Challenges in the Integration of Soft Skills in Teaching Technical Courses: Lecturer's Perspectives." Asian Journal of University Education 5, no. 2 (2009): 67-81.

Harde, Rozanne, and Sandy Bugeja. "Team-Based Learning in the First-Year English Classroom." In Team-Based Learning in the Social Sciences and Humanities: Group Work That Works to Generate Critical Thinking and Engagement, edited by Michael Sweet and Larry K. Michaelsen, 143-158. Sterling: Stylus Publishing, 2012.

Hawkins, John, N. Zhou, and J. Lee. "China: Balancing the Collective and the Individual." In Value Education for Dynamic Societies: Individualism or Collectivism, edited by William K. Cummings, Maria T. Tatto, and John Hawkins 191-206. Hong Kong: Comparative Educational Research Center, 2001.

Hing, Helena W. S. "Characteristics of Chinese Students' Learning Styles." International Association of Computer Science and Information Technology 62, no. 8 (2013): 36-39.

Hong, Ying-yi. "A Dynamic Constructivist Approach to Culture: Moving from Describing Culture to Explaining Culture." In Understanding Culture: Theory, Research, and Application, edited by Robert S. Wyer, Chi-Yue Chiu, and Ying-yi Hong. New York: Taylor \& Francis, 2009.

Hunt, Daniel P., Paul Haidet, John H. Coverdale, and Boyd Richards. "The Effect of Using Team Learning in an Evidence-Based Medicine Course for Medical Students." Teaching and Learning in Medicine 15, no. 2 (2003): 131-139.

Hunter, Erica, and Bryan Robinson. "Connecting Students to the Social World: Using Team-Based Learning in the Sociology Classroom." In Team-Based Learning in the Social Sciences and Humanities: Group Work That Works to Generate Critical Thinking and Engagement, edited by Michael Sweet and Larry K. Michaelsen, 81-97. Sterling: Stylus Publishing, 2012.

Jakobsen, Krisztina V., Megan McIlreavy, and Sarah Marrs. "Team-Based Learning: The Importance of Attendance." Psychology Teaching and Learning 13, no. 1 (2014): 25-31.

Jaramillo, James A. "Vygotsky's Sociocultural Theory and Contributions to the Development of Constructivist Curricula." Education 117, no. 1 (1996): 133-140.

Jarvis, Peter. The Theory and Practice of Teaching. 2nd ed. New York: Routledge, 2006.

Ji, Li-Jun, Peng Keyin, and Richard Nisbett. "Culture, Control, and Perception of Relationships in the Environment." Journal of Personality and Social Psychology 78, no. 5 (2000): 943-955. 
Jolly, Anne. "STEM vs. STEAM: Do the Arts Belong?" November 18, 2014. http://www.edweek.org/tm/articles/2014/11/18/ctq-jolly-stem-vssteam.html.

Kahn, Joel S. Southeast Asian Identities: Culture and the Politics of Representation in Indonesia, Malaysian, Singapore and Thailand. Singapore: Institute of Southeast Asian Studies, 1998.

Kent, Shawn, Jeanne Wanzek, Elizabeth Swanson, and Sharon Vaughn. "TeamBased Learning for Students with High-Incidence Disabilities in High School Social Studies Classrooms." Learning Disabilities Research and Practice 30, no. 1 (2015): 3-14.

Kubista-Hovis, Scott. "I Don't Dare Teach with Inquiry-Based Teaching Methods When I Have State Testing Breathing Down My Neck." In Team-Based Learning in the Social Sciences and Humanities: Group Work That Works to Generate Critical Thinking and Engagement, edited by Michael Sweet and Larry K. Michaelson, 291-300. Sterling: Stylus Publishing, 2012.

LaForce, Melanie, Elizabeth Noble, Heather King, S. Holt, and Jeanne Century. The 8 Elements of Inclusive STEM High Schools. Chicago: University of Chicago, 2014.

Langley, Ann, Henry Mintzberg, Patricia Pitcher, Elizabeth Posada, and Jan Saint-Macary. "Opening Up Decision Making: The View from the Black Stool." Organization Science 6, no. 3 (1995): 260-279.

Lantolf, James P., ed. "Introducing Sociocultural Theory." In Sociocultural Theory and Second Language Learning, 1-26. Oxford: Oxford University Press, 2000.

Lau, S. "Collectivism's Individualism: Value Preference, Personal Control, and the Desire for Freedom Among Chinese in Mainland China, Hong Kong, and Singapore." Personality and Individual Differences 13, no. 3 (1992): 361-366.

Lee, Wing On. "The Cultural Context for Chinese Learners: Conceptions of Learning in the Confucian Tradition." In The Chinese Learner: Cultural, Psychological, and Contextual Influences, edited by David Watkins and John Biggs, 25-41. Hong Kong: CERC and ACER, 1996.

Littlewood, William. "Students' Attitudes to Classroom English Learning: A Cross-Cultural Study." Language Teaching Research 5, no. 1 (2001): 3-28.

Liu, Shu-Hsien. "The Use of Analogy and Symbolism in Traditional Chinese Philosophy." Journal of Chinese Philosophy 1, no. 3-4 (1974): 313-338.

Lloyd, Geoffery. "Science in Antiquity: The Greek and Chinese Cases and Their Relevance to the Problems of Culture and Cognition." In Modes of Thought: Explorations in Culture and Cognition, edited by David R. Olson and Nancy Torrance, 15-33. Cambridge: Cambridge University Press, 1996. 
Maehr, M. L., and J. Nicholls. "Culture and Achievement Motivation: A Second Look." In Studies in Cross-Cultural Psychology, edited by Neil Warren, 221267. New York: Academic Press, 1980.

Maxwell, Amanda, Guy Curtis, and Lucia Vardanega. "Does Culture Influence Understanding and Perceived Seriousness of Plagiarism?" International Journal for Educational Integrity 4, no. 2 (2008): 25-40.

McClelland, David. The Achieving Society. Princeton: Von Nostrand, 1961.

Mcinerney, Michael, and L. Dee Fink. "Team-Based Learning Enhances LongTerm Retention and Critical Thinking in an Undergraduate Microbial Physiology Course." Journal of Microbiology and Biology Education 4 (2003): 3-12.

McLaughlin, Jacqueline, Mary Roth, Dylan Glatt, Nastaran Gharkholonarehe, Christopher Davidson, LaToya Griffin, Denise Esserman, and Russell Mumper. "The Flipped Classroom: A Course Redesign to Foster Learning and Engagement in a Health Professions School." Academic Medicine 89, no. 2 (2014): 236-243.

Michaelsen, Larry K., Arletta Knight, and L. Dee Fink. Team-Based Learning: A Transformative Use of Small Groups in College Thinking. Sterling: Stylus Publishing, 2004.

Michaelsen, Larry K., and Michael Sweet. "The Essential Elements of TeamBased Learning." New Directions for Teaching and Learning 116, no. (2008): $7-27$.

Michaelsen, Larry K., Warren E. Watson, and Robert H. Black. "A Realistic Test of Individual Versus Group Consensus Decision Making." Journal of Applied Psychology 74, no. 5 (1989): 834-839.

Ministry of Higher Education Malaysia. The National Graduate Employability Blueprint 2012-2017. Serdang: Universiti Putra Malaysia Press, 2012.

Moffett, Jennifer. "Twelve Tips for 'Flipping' the Classroom." Medical Teacher 37 , no. 4 (2014): 331-336.

Morgan, Tom. "Using Technology to Enhance Learning: Changing the Chunks." Learning and Leading with Technology 23, no. 5 (1996): 49-51.

Morshidi, Sirat, Chan Lean Heng, Munir Shuib, Shukran Abdul Rahman, Seri R. A. Kamil, and Jasvir K. N. Singh. "Employability of Graduates in Malaysia." In Employability of Graduates in Malaysia Graduate Employability in Asia, edited by UNESCO, 24-37. Bangkok: UNESCO, 2012.

Murphy, David. “Offshore Education: A Hong Kong Perspective." Australian Universities Review 30, no. 2 (1987): 43-44.

Nakamura, Hajime. The Ways of Thinking of Eastern Peoples. New York: Greenwood Press, 1988.

Nelson, Gayle L. "Comments on Ruth Spack's 'The Rhetorical Construction of Multilingual Students': Categorizing, Classifying, Labeling: A Fundamental Cognitive Process.” TESOL Quarterly 32, no. 4 (1998): 727-732. 
Neuman, Yair, and Zvi Bekerman. "Cultural Resources and the Gap Between Educational Theory and Practice." Teachers College Record 103, no. 3 (2000): 471-484.

Nguyen, Phuong-Mai, Cees Terlouw, and Albert Pilot. "Cooperative Learning vs Confucian Heritage Culture's Collectivism: Confrontation to Reveal Some Cultural Conflicts and Mismatch.” Asia Europe Journal 3, no. 3 (2005): 403419.

Nisbett, Richard E., Peng Kaiping, Incheol Choi, and Ara Norenzayan. "Culture and Systems of Thought: Holistic Versus Analytic Cognition." Psychological Review 108, no. 2 (2001): 291-310.

Niu, Weihua, John Zhang, and Yang Yingrui. "Does Culture Always Matter: For Creativity, Yes, for Deductive Reasoning, No!" In Creativity and Reason in Cognitive Development, edited by James C. Kaufman and John Baer, 282-296. New York: Cambridge University Press, 2006.

Norenzayan, Ara, and Ricard E. Nisbett. "Culture and Causal Cognition." Current Directions in Psychological Science 9, no. 4 (2000): 132-135.

Norenzayan, Ara, Edward E. Smith, Beom Jun Kim, and Richard E. Nisbett. "Cultural Preferences for Formal Versus Intuitive Reasoning." Cognitive Science 26, no. (2002): 653-684.

Norizan, Abdul Razak, Hazita Azman, Mohd Salehuddin Abdul Aziz, Azizah Yaacob, and Wong Fook Fei. Kajian Pembentukan Ujian Kompetensi Bahasa Inggeris bagi Pelajar IPTA di Malaysia (A Study of Developing an English Language Competency Test for Malaysian IPTA Students). Kuala Lumpur, Malaysia: Intensification of Research in Priority Areas (IRPA), 2007.

Norris, C., and J. L. Poirot. Problem Solving and Critical Thinking for Computer Science Educators. Eugene: International Society for Technology in Education, 1990.

Novera, Isvet A. "Indonesian Postgraduate Students Studying in Australia: An Examination of Their Academic, Social and Cultural Experiences." International Education Journal 5, no. 4 (2004): 475-487.

O'Dwyer, Shaun. "Deflating the 'Confucian Heritage Culture' Thesis in Intercultural and Academic English Education." Language, Culture and Curriculum 30, no. 2 (2017): 198-211.

Oliver, K. M. "Methods for Developing Constructivism Learning on the Web." Educational Technology 40, no. 6 (2000): 5-16.

Organisation for Economic Co-operation and Development. "The Future of Work Is Now. Are We Ready?” Accessed June 20, 2019, from http://www. oecd.org/employment/outlook/.

Park, Clara C. "Learning Style Preferences of Asian American (Chinese, Filipino, Korean, and Vietnamese) Students in Secondary Schools." Equity and Excellence in Education 30, no. 2 (1997): 68-77. 
Park, Jae. "Metamorphosis of Confucian Heritage Culture and the Possibility of an Asian Education Research Methodology." Comparative Education 47, no. 3 (2011): 381-393.

Parmelee, Dean, Larry Michaelsen, Sandy Cook, and Patricia Hudes. "TeamBased Learning: A Practical Guide: AMEE Guide No. 65." Medical Teacher 34, no. 5 (2012): 275-287.

Peng, Kaiping, and Richard E. Nisbett. "Culture, Dialectics, and Reasoning About Contradiction." American Psychologist 54 (1999): 741-754.

Peters-Burton, Erin E., Sharon Lynch, Tara Behrend, and Barbara Means. "Inclusive STEM High School Design: 10 Critical Components." Theory into Practice 53, no. 1 (2014): 64-71.

Piaget, Jean. "The Psychogenesis of Knowledge and Its Epistemological Significance." In Language and Learning, edited by Massimo Piatelli-Palmarini, 23-34. Cambridge: Harvard University Press, 1980.

Pierce, Richard, and Jeremy Fox. "Instructional Design and Assessment: Vodcasts and Active Learning Exercises in a 'Flipped Classroom' Model of a Renal Pharmacotherapy Module." American Journal of Pharmacentical Education 76, no. 10 (2012): 1-5.

Purdie, Nola, John Hattie, and Graham Douglas. "Student Conceptions of Learning and Their Use of Self-Regulated Learning Strategies: A CrossCultural Comparison." Journal of Educational Psychology 88, no. 1 (1996): 87-100.

Rania, Nadia, Laura Migliorini, and Stefania Rebora. "Team-Based Learning and Life Skills: A Qualitative Study from Psychological Students' Point of View." Health Science Journal 10, no. 1/2 (2015): 1-7.

Raudsepp, Eugene. “Can You Trust Your Hunches?” Management Review 49, no. 4 (1960): 7 .

Riley, Susan. "STEAM in the Classroom Look-For List." February 1, 2018. https://educationcloset.com/2018/02/01/steam-in-the-classroom/.

Robertson, Bill, and Christine Reimers. "Team-Based Learning for Critical Reading and Thinking in the Literature and Great Books Courses." In Team-Based Learning in the Social Sciences and Humanities: Group Work That Works to Generate Critical Thinking and Engagement, edited by Michael Sweet and Larry K. Michaelsen, 129-141. Sterling: Stylus Publishing, 2012.

Roehl, Amy, Shweta L. Reddy, and Gayla J. Shannon. “The Flipped Classroom: An Opportunity to Engage Millennial Students Through Active Learning Strategies." Journal of Family and Consumer Science 105, no. 2 (2013): 4449.

Rosenberg, Michael S., David L. Westling, and James McLeskey. Special Education for Today's Teachers: An Introduction. Upper Saddle River: Prentice Hall, 2008 . 
Ross, Lee. "The Intuitive Psychologist and His Shortcomings." In Advances in Experimental Social Psychology, edited by Leonard Berkowitz, 173-220. New York: Academic Press, 1977.

Salili, Farideh. "Accepting Personal Responsibility for Learning." In The Chinese Learner: Cultural, Psychological and Contextual Influences, edited by David A. Watkins and John B. Biggs, 86-105. Hong Kong: CERC and ACER, 1996.

Schwab, Klaus. The Fourth Industrial Revolution. Geneva: World Economic Forum, 2016.

Selz, O. "Attempt to Raise the Level of Intelligence." Zeitschrift fur Psychologie 134 (1935): 236-301.

Seo, Seonjin, and Mirka Koro-Ljungberg. "A Hermeneutical Study of Older Korean Students' Experiences in American Higher Education: From Confucianism to Western Educational Values." Journal of Studies in International Education 9, no. 2 (2005): 164-187.

Shi, Lijing. "The Successors to Confucianism or a New Generation? A Questionnaire Study on Chinese Students' Culture of Learning English." Language, Learning and Culture 19, no. 1 (2006): 122-147.

Sowden, Colin. "Plagiarism and the Culture of Multilingual Students in Higher Education Abroad." ELT Journal 59, no. 3 (2005): 226-233.

Spence, Janet T. "Achievement American Style: The Rewards and Costs of Individualism." American Psychologist 40, no. 12 (1985): 1285-1295.

Spender, J. C. Industry Recipe: An Enquiry into the Nature and Sources of Managerial Judgment. New York: Basil Blackwell, 1989.

Sternberg, Robert J., and Wendy M. Williams. Educational Psychology. Boston: Allyn \& Bacon, 2002.

Strayer, Jeremy. "How Learning in an Inverted Classroom Influences Cooperation, Innovation, and Task Orientation." Learning Environments Research 15, no. 2 (2012): 171-193.

Subramaniam, Ganakumaran. "Confronting Asian Concerns in Engaging Learners to Online Education." International Education Studies 1, no. 4 (2008): 10-18.

Sweet, Michael, and Larry Michaelsen. Team-Based Learning in the Social Sciences and Humanities: Group Work That Works to Generate Critical Thinking and Engagement. Sterling: Stylus Publishing, 2012.

Talley, Cheryl, and Stephen Scherer. "The Enhanced Flipped Classroom: Increasing Academic Performance with Student-Recorded Lectures and Practice Testing in a 'Flipped' STEM Course." The Journal of Negro Education 82, no. 3 (2013): 339-347.

Tao, Vivienne, and Hong Ying-Yi. "When Academic Achievement Is an Obligation-Perspectives from Social-Oriented Achievement Motivation." Journal of Cross-Cultural Psychology 45, no. 1 (2014): 110-136. 
Taylor, Insup, and Martin Taylor. Writing and Literacy in Chinese, Korean and Japanese. Amsterdam: John Benjamins, 2014.

Tu, Weiming. Confucian Thought: Selfhood as Creative Transformation. Albany: State University of New York Press, 1985.

Tucker, Jane, and Mary Brewster. "Evaluating the Effectiveness of Team-Based Learning in Undergraduate Courses." Journal of Criminal Justice Education 26, no. 4 (2015): 446-470.

Turner, Jane. Language in the Academy. Bristol: Multilingual Matters, 2011.

Turuk, Mamour C. "The Relevance and Implications of Vygotsky's Sociocultural Theory in the Second Language Classroom." ARECLS 5 (2008): 244-262.

Tweed, Roger G., and Darrin R. Lehman. "Learning Considered Within a Cultural Context: Confucian and Socratic Approaches." American Psychologist 57, no. 2 (2002): 89-99.

Vestberg, Hans. "Why We Need Both Science and Humanities for a Fourth Industrial Revolution Education." September 21, 2018. https://www. weforum.org/agenda/2018/09/why-we-need-both-science-and-humanitiesfor-a-fourth-industrial-revolution-education/.

Vygotsky, Lev. Thought and Language. Cambridge: MIT Press, 1962.

Wang, Junju. "Understanding the Chinese Learners from a Perspective of Confucianism." In Researching Cultures of Learning, edited by Martin Cortazzi and Jin Lixian, 61-79. London: Palgrave Macmillan, 2013.

Wanzek, Jeanne, Sharon Vaughn, Shawn Kent, Elizabeth Swanson, Greg Roberts, Martha Haynes, Anna-Maria Fall, Stephanie Stillman-Spisak, and Michael Solis. "The Effects of Team-Based Learning on Social Studies Knowledge Acquisition in High School." Journal of Research on Educational Effectiveness 7, no. 2 (2014): 183-204.

Wanzek, Jeanne, Shawn Kent, Sharon Vaughn, Elizabeth Swanson, Greg Roberts, and Martha Haynes. "Implementing Team-Based Learning in Middle School Social Studies Classes." Journal of Educational Research 108, no. 4 (2014): 331-344.

Watkins, David. A., and John Biggs. Teaching the Chinese Learner: Psychological and Pedagogical Perspectives. Hong Kong and Melbourne: CERC and ACER, 2001.

Wilson, Stephanie G. "The Flipped Class: A Method to Address the Challenges of an Undergraduate Statistics Course." Teaching of Psychology 40, no. 3 (2013): 193-199.

Witkin, Herman A., and John W. Berry. "Psychological Differentiation in CrossCultural Perspective." Journal of Cross-Cultural Psychology 6, no. 1 (1975): 4-87.

World Economic Forum. The Future of Jobs Report 2018. Geneva: World Economic Forum, 2018. 
. "What Is the Fourth Industrial Revolution?" CN Crypto News, April 27, 2019. https://www.cncryptonews.com/what-is-the-fourth-industrialrevolution/.

Wu, David. "Parental Control: Psycho-Cultural Interpretations of Chinese Patterns of Socialization." In Growing Up the Chinese Way: Chinese Child and Adolescent Development, edited by Lau Sing, 1-28. Hong Kong: The Chinese University of Hong Kong Press, 1996.

Yang, Kuo-Shu. "Chinese Personality and Its Change." In The Psychology of the Chinese People, edited by Michael H. Bond, 106-170. Hong Kong: Oxford University Press, 1986.

Yang, Kuo-Shu, and Yu An-Bang. "Social-Oriented and Individual-Oriented Achievement Motives: Conceptualization and Measurement." Paper presented at the Symposium on Chinese Personality and Social Psychology for the XXIVth International Congress of Psychology, Sydney, 1988.

- "Sinicization of Psychological Research in Chinese Society: Directions and Issues (in Chinese)." In The Sinicization of Social and Behavioral Science Research in Chinese Societies, edited by Yang Kuo-Shu and Ch'ung-i Wen, 153-187. Taipei: Institute of Ethnology, 1982.

Yee, Mei Hong, Widad Binti Othman, Jailani Bin Md Yunos, Tee Tze Kiong, Razali Bin Hassan, and Mimi Mohaffzya Binti Mohamad. "The Level of Marzano Higher Order Thinking Skills Among Technical Education Students." International Journal of Social Science and Humanity 1, no. 2 (2011): $121-125$.

Yu, An-Bang. "Socializational Factors of Individual's Achievement Motivation in Family." Bulletin of the Institute of Ethnology 71 (1991): 87-132.

- "Ultimate Life Concerns, Self, and Chinese Achievement Motivation." In The Handbook of Chinese Psychology, edited by Michael H. Bond, 227-246. Hong Kong: Oxford University Press, 1996.

Yu, An-Bang, and Yang Kuo-Shu. "Social-Oriented and Individual-Oriented Achievement Motivation: A Conceptual and Empirical Analysis (in Chinese)." Bulletin of the Institute of Ethnology, Academia Sinica 64 (1987): 51-98.

-. "The Nature of Achievement Motivation in Collectivist Societies." In Individualism and Collectivism: Theory, Method, and Applications, edited by Uichol Kim, Harry C. Triandis, Cigdem Kagitcibasi, Sang-Chin Choi, and Gene Yoon, 239-250. Thousand Oaks: Sage, 1994.

Yuan, Lijun. "Confucian and Feminist Notions of Relational Self and Reciprocity: A Comparative Study.” Journal of East-West Thought. Accessed June 25, 2019, from https://www.cpp.edu/ jet/Documents/JET/Jet17/Yuanl-9.pdf.

Zgheib, N. K., J. A. Simaan, and R. Sabra. "Using Team-Based Learning to Teach Pharmacology to Second Year Medical Students Improves Student Performance." Medical Teacher 32, no. 2 (2010): 130-135. 
Open Access This chapter is licensed under the terms of the Creative Commons Attribution 4.0 International License (http://creativecommons.org/licenses/ by $/ 4.0 /$ ), which permits use, sharing, adaptation, distribution and reproduction in any medium or format, as long as you give appropriate credit to the original author(s) and the source, provide a link to the Creative Commons license and indicate if changes were made.

The images or other third party material in this chapter are included in the chapter's Creative Commons license, unless indicated otherwise in a credit line to the material. If material is not included in the chapter's Creative Commons license and your intended use is not permitted by statutory regulation or exceeds the permitted use, you will need to obtain permission directly from the copyright holder.

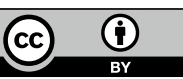

